Željko Lovrinčević*

Davor Mikulić ***

Damira Ke ček $k^{* * *}$
JEL klasifikacija: A10, C67, R15

Izvorni znanstveni rad

https://doi.org/10.32910/ep.72.3.6

\title{
IZLAZNA GOSPODARSKA STRATEGIJA HRVATSKE U VRIJEME PANDEMIJE COVID-19 I ZNAČAJ REGIONALNE STRUKTURE GOSPODARSTVA
}

Cilj je ovoga rada, analizom multiplikativnih učinaka $i$ intenziteta regionalne povezanosti, identificirati sektore s najvećim potencijalom za ublažavanje negativnih gospodarskih posljedica širenja COVID-19 virusa u Hrvatskoj. Hrvatska je podijeljena u dvije regije: Kontinentalna Hrvatska i Jadranska Hrvatska. U izradi regionalnih input-output tablica korištena je metodologija međusektorskih lokacijskih kvocijenata (Cross-industry location quotient, CILQ). Metoda se temelji na specijalizaciji pojedinih regija u proizvodnji određenih skupina proizvoda, a temeljem čega se nacionalni tehnički koeficijenti prilagođavaju na razini pojedinih regija. U istraživačkom smislu doprinos rada temelji se na nepostojanju empirijske literature koja bi se bavila regionalnom input-output analizom za hrvatsko gospodarstvo. Rezultati rada mogu se koristiti i kao podloga za definiranje izlazne ekonomske strategije usmjerene na oporavak gospodarstva i brži izlazak iz recesije. Najveći multiplikativni učinci i najveći intenzitet regionalne povezanosti uočen je u određenim sektorima prerađivačke industrije, poljoprivredi $i$ građevinarstvu. Ova skupina djelatnosti može se uz određene mjere opreza odvijati na dosadašnji način bez velikih rizika za širenje virusa. Poticanje

* Ž. Lovrinčević, dr.sc., znanstveni savjetnik u trajnom zvanju, Ekonomski institut, Zagreb, (e-mail: zlovrincevic@eizg.hr).

** D. Mikulić, dr.sc., znanstveni savjetnik u trajnom zvanju, Ekonomski institut, Zagreb, (e-mail: dmikulic@eizg.hr).

**** D. Keček, dr.sc., docentica, Sveučilište Sjever, Sveučilišni centar Varaždin, (e-mail: dkecek@ unin.hr). Rad je primljen u uredništvo 29.04.2020. godine, a prihvaćen je za objavu 19.10.2020. godine. 
ovih aktivnosti daje pozitivne rezultate već u kratkom roku, a zbog visokih multiplikativnih učinaka, pozitivni poticaj širi se i na ostale djelatnosti i regije. Osim ovih djelatnosti naglasak treba biti i na unapređivanju sektora zdravstva i sektora informacijsko-komunikacijskih tehnologija, kod kojih su neizravni gospodarski učinci nešto niži, ali koji će biti ključni za nesmetano odvijanje gospodarske aktivnosti u budućem razdoblju. Sektor turizma ima vrlo plitke multiplikatine učinke, ali nadprosječno velik udio isporuka za finalnu potrošnju, a time i utjecaj na prihode državnog proračuna.

Ključne riječi: regionalne input-output tablice, multiplikativni učinci, Covid-19 virus, lokacijski kvocijenti.

\section{UVOD}

Regionalne input-output (RIO) tablice koristan su alat za analizu međusobne povezanosti pojedinih proizvodnih sektora i regija. Raspoloživost RIO tablica može poslužiti za brojne analitičke svrhe, ali i za formuliranje mjera ekonomske politike. To je posebice značajno u uvjetima djelovanja određenih eksternih šokova koji utječu na određene gospodarske sektore ili regije, a budući se tehnološki procesi ne mogu značajno promijeniti u kratkom roku, takvi se učinci distribuiraju i na ostale sektore i područja. Pojava i širenje COVID-19 virusa u uvjetima nepostojanja cjepiva dovela je do uvođenja epidemioloških mjera koje ograničavaju kretanje ljudi i potpuno mijenjaju ne samo strukturu finalne potražnje, već i načine na koje se pojedine aktivnosti mogu odvijati bez ugrožavanja zdravlja pojedinaca. Vlade gotovo svih zemalja svijeta poduzimaju odgovarajuće epidemiološke mjere u cilju smanjivanja kontakata među ljudima i usporavanja širenja zaraze. Uslijed novonastalih okolnosti izazvanih širenjem pandemije COVID-19, u mnogim se zemljama može očekivati značajniji pad gospodarske aktivnosti. Svaka država, pa tako i Hrvatska, će tražiti ravnotežu između epidemioloških ograničenja i oživljavanja gospodarstva. Postavlja se pitanje kojom dinamikom i koje djelatnosti prve vraćati u uobičajeni ritam gospodarskog poslovanja. Često se taj proces naziva definiranje izlazne strategije (eng. exit strategy).

Recentna istraživanja (Fernandes, 2020) zaključuju da će gospodarstva orijentirana na usluge biti najsnažnije pogođena krizom uzrokovanom pojavom virusa. Međutim, isti autor ukazuje i na prelijevanje krize iz uslužnih djelatnosti na ostatak gospodarstva i širenje negativnih učinaka kroz cijeli reprodukcijski lanac. Prema procjenama ovog istraživanja, svaki dodatni mjesec krize i postojanja ograničenja za obavljanje gospodarskih djelatnosti, u prosjeku će rezultirati smanjenjem gospodarstva intenziteta 2,5-3\% svjetskog gospodarstva. Fornaro i 
Wolf (2020) pokazuju kako širenje epidemije rezultira najprije šokom smanjenja potražnje, a iza kojeg slijedi smanjenje ponude i nastavak negativnih učinka putem učinka spirale (smanjenje potražnje i ponude se međusobno nadovezuju i u sljedećim krugovima širenja negativni učinak je sve veći). Autori uglavnom sugeriraju vođenje agresivnije ekonomske politike ciljane na povećanje investicija, a kako bi se zaustavilo djelovanje negativnog spiralnog učinka i pokrenulo gospodarstvo. Loayza i Pennings (2020) sugeriraju primjenu kratkoročnih mjera usmjerenih na izbjegavanje otkaza radnicima i stečaja poduzetnika u prvom razdoblju najvećih restrikcija u kretanju ljudi. Ublažavanjem restrikcija javlja se potreba za makroekonomskom politikom usmjerenom na oporavak gospodarstva, a koja podrazumijeva određeni stimulans gospodarstvu koordinacijom monetarne i fiskalne politike. Autori ukazuju da bi učinci takve ekonomske politike mogli biti nešto manje učinkoviti u zemljama u kojima je monetarna transmisija slaba i fiskalni multiplikatori niži. Potreba za definiranjem izlazne strategije u središtu je i brojnih medijskih napisa širom svijeta. Europska komisija (2020) također je iskazala potrebu za definiranjem koordinirane izlazne strategije uz sveobuhvatan program oporavka praćen investicijskim planom.

Hrvatska pripada skupini zemalja čija će ekonomska aktivnost biti vjerojatno značajno smanjena upravo zbog strukture gospodarstva i izrazito visokog udjela uslužnih djelatnosti, a čije je odvijanje ograničeno. Kao mjera ublažavanja negativnih učinaka na smanjenje zaposlenosti, Vlada je donijela odluku o proračunskom financiranju plaća u visini blago iznad minimalne plaće za zaposlene koje bi inače ostali bez radnog mjesta zbog nemogućnosti poslovanja zbog loše epidemiološke situacije. Poboljšanje epidemiološke situacije omogućilo je postupno ublažavanje mjera socijalnog distanciranja uz fazno otvaranje mogućnosti poslovanja određenih skupina poduzetnika. Ipak, učinci pada ekonomske aktivnosti i troškovi nepovratnih sredstava postavljaju ozbiljan izazov za održivost stanja javnih financija.

Cilj je ovog rada temeljem analize multiplikativnih učinaka i međusobne regionalne povezanosti Kontinentalne i Jadranske Hrvatske identificirati sektore koji mogu imati potencijal da se preusmjeravanjem dijela izdataka za nepovratna sredstva u stimuliranje ekonomske aktivnosti osigura prevladavanje recesije ili barem ublažavanje njenih negativnih posljedica. Za razliku od ranijeg razdoblja u kojem je politika poticanja pojedinih sektora bila zabranjena zbog narušavanja slobodnog tržišta Europske unije, u postojećim uvjetima zdravstvene ugroženosti i zabrane kretanja, zemljama članicama bit će dozvoljena određena fleksibilnost u poticanju gospodarstva, a kako bi se ublažile negativne gospodarske posljedice.

U izradi RIO tablica korištena je metoda međusektorskih lokacijskih kvocijenata (Cross-industry location quotient, CILQ). Metoda se temelji na specijalizaciji pojedinih regija u proizvodnji određenih skupina proizvoda, a temeljem čega se nacionalni tehnički koeficijenti prilagođavaju na razini pojedinih regija. U istraži- 
vačkom smislu doprinos rada temelji se na nepostojanju empirijske literature koja bi se bavila RIO analizom za hrvatsko gospodarstvo. Raspoloživi empirijski radovi za hrvatsko gospodarstvo uglavnom su proučavali aktivnost određenih sektora gospodarstva, ali isključivo na nacionalnoj razini. U recentnim empirijskim istraživanjima temeljem input-output $(\mathrm{IO})$ tablice za hrvatsko gospodarstvo proučavani su učinci investicija u obnovljive izvore energije (Mikulić, Lovrinčević i Keček, 2018; Keček, Mikulić i Lovrinčević, 2019), doprinos sektora informacijsko-komunikacijskih tehnologija (Keček, 2019; Keček, Boljunčić i Mikulić, 2019), učinci turizma (Mikulić, Keček i Žajdela Hrustek, 2017; Ivandić i Šutalo, 2018), rast izvoza i razvoj prerađivačke industrije (Buturac, Mikulić i Palić, 2019), te učinci energetske obnove više-stambenih zgrada na gospodarstvo i klimatske promjene (Mikulić, Slijepčević i Buturac, 2020).

Struktura rada je sljedeća. Nakon uvodnog poglavlja slijedi kratki pregled literature koji daje osnovni prikaz analitičkih mogućnosti RIO analize. Metodologija korištena u radu definirana je u trećem poglavlju, a rezultati analize u četvrtom. Peto poglavlje daje zaključak rada. Na kraju rada nalazi se popis literature, kao i nekoliko priloga koji detaljnije prikazuju rezultate istraživanja.

\section{KRATKI PREGLED LITERATURE}

U nacionalnim IO tablicama prikazani su tokovi roba i usluga između aktivnih proizvodnih sektora nacionalnog gospodarstva u određenom razdoblju ${ }^{1}$. Međutim, IO tablice sastavljene na nacionalnoj razini ne prikazuju razlike u gospodarskom razvoju između različitih regija unutar pojedine zemlje. Stoga se u novije vrijeme sve veći naglasak stavlja na izradu RIO tablica koje pružaju detaljnije informacije o toku roba i usluga među proizvodnim sektorima pojedine regije stvarajući tako bazu podataka za relevantnu regionalnu ekonomsku analizu. Izrada RIO tablica u velikoj mjeri ovisi u dostupnim statističkim podacima, kao i u dosljednosti i usklađenosti podataka na regionalnoj i nacionalnoj razini (United Nations, 2018). RIO analiza snažan je analitički alat koji nositeljima ekonomskih politika omogućuje analizu i detaljnije sagledavanje regionalnih karakteristika te gospodarskih veza između regija, te posljedično i razvoj mjera i strategija specifičnih za pojedinu regiju.

Interes za regionalni i ruralni razvoj te potreba za analizom regionalnih i međuregionalnih utjecaja potiču izradu regionalnih, međuregionalnih i multiregi-

1 Detaljnije o IO analizi i IO tablicama vidjeti u ten Raa (2005), Miller and Blair (2009), Mikulić (2018). 
onalnih IO tablicama te stvaranje kvantitativnih modela temeljenih na regionalnih, međuregionalnih i multiregionalnih tablicama (Oosterhaven i Polenske, 2009). Regionalne nejednakosti jedan su razloga izrade međuregionalnih IO tablica za one koji planiraju politiku na nacionalnoj i regionalnoj razini kao i istraživače unutar i izvan Kine (Okamoto i Ihara, 2005).

Izrada 14 pojedinačnih RIO tablica za Češku opisana je u Vltavská i Sixta (2017). Izrada tablica temeljena je na pretpostavci da se sjedište tvrtke i sve podružnice klasificiraju prema glavnoj djelatnosti cijele tvrtke što utječe na interpretaciju podataka i pretvorbu podataka iz proizvod-djelatnost ili djelatnost-proizvod. Nadalje, autori pretpostavljaju da svi podaci potječu iz računovodstva pojedinih tvrtki i ne bilježi se prodaja između firmi. U izradi RIO tablica za Češku naglasak se stavlja na procjenu vektora outputa temeljem kombinacije regionalnih i nacionalnih računa. Vektori outputa procijenjeni su korištenjem ključeva alokacije za svaku industriju u svih četrnaest regija. Konačno, pretpostavlja se ista tehnologija kao u izradi simetrične IO tablice.

Od kreatora regionalnih ekonomskih politika očekuje se usmjerenost na rješavanje specifičnih regionalnih problema poput nezaposlenosti. RIO tablice najprikladniji su alat za analizu utjecaja regionalnih politika na zaposlenosti. Tako je Sixta (2017) analizirao proces obrade podataka o zaposlenosti na regionalnoj razini na temelju RIO tablica za 14 regija Češke. Podaci o zaposlenosti koji se analiziraju iskazani su po broju zaposlenih osoba. Razlog za odabir takvog prikaza podataka o zaposlenosti leži u jednostavnost podataka te u očekivano većoj kvaliteti takvih podataka na regionalnoj razini. Objavljeni podaci o regionalnoj zaposlenosti najprije se raspodijele po odjeljcima u skladu s podacima nacionalnih računa, a zatim se računa razlika između regionalne zaposlenosti po sektorima i zaposlenosti po djelatnostima. Analiza zaposlenosti po regijama omogućava prepoznavanje regionalnih specifičnosti i njihovu vezu s drugim regijama.

Osim za proučavanje regionalnog i ruralnog razvoja, RIO tablice koriste se i za analizu određenih sektora u regiji. Tako su Vltavská i Fischer (2017) na temelju RIO tablica Češke procijenili učinke izdataka u visokom obrazovanju na gospodarstvo regija u Češkoj. Također, učinci izdataka za visoko obrazovanje uspoređeni su s učincima izdataka na usluge informacijsko-komunikacijskih tehnologija, istraživanje i razvoj te turizam. Izračunati multiplikatori za obrazovne usluge niži su od multiplikatora dobivenih za informacijsko-komunikacijske tehnologije, istraživanje i razvoj te turizam. Semerak, Zigic, Loizou i Golemanova-Kuhar (2010) primijenili su GRIT (eng. Generation of Regional Input-Output Tables) metodologiju regionalizacije. Na temelju RIO tablica analiziran je doprinos poljoprivredno-prehrambenog lanca proizvodnje ruralnih i udaljenih regija u Njemačkoj, Grčkoj i Češkoj. Rezultati analize ukazuju na veliki značaj analiziranog sektora u promatranim regijama posebice kada je riječ o zaposlenosti. 


\section{METODOLOGIJA}

RIO tablice mogu se izrađivati na više načina. Jedan od načina izrade RIO tablica temeljen je na podacima dobivenim specijalnim statističkim istraživanjima usmjerenim na dobivanje podatkovne osnove za procjenu regionalne strukture intermedijarne potrošnje. Takav pristup omogućuje izravan izračun tablica ponude i potražnje, a time i regionalnih IO tablica. Međutim samo prikupljanje podataka iznimno je složen i skup zadatak. Alternativni pristup izrade RIO jesu metode za procjenu regionalnih IO tablica koje se ne oslanjaju na specijalna statistička istraživanja, već primjenu odgovarajućih statističkih i matematičkih metoda. Takvi pristupi uglavnom se sastoje u prilagodbi nacionalnih IO tablica korištenjem lokacijskih kvocijenata (eng. location quotients, LQ) (Bonfiglio i Chelli, 2008; Flegg i Tohmo, 2013; Miller i Blair, 2009). Uspoređuju se regionalni i nacionalni outputi, zbog dostupnosti podataka obično podaci o broju zaposlenih u industrijama kako bi se kvantificirala sposobnost regionalnih industrija da zadovolji regionalne potrebe za svojim proizvodom (Boero, Edwards i Rivera, 2018).

Više je načina definiranja lokacijskih kvocijenata za procjenu RIO tablica (Miller i Blair, 2009; Szabó, 2015). Najjednostavnija varijanta lokacijskog kvocijenta je jednostavni lokacijski kvocijent (eng. Simple location quotient). Purchasesonly location quotient (PLQ) uzima u obzir samo one sektore koji koriste proizvode određenog sektora u svojim proizvodnim procesima. Međusektorski lokacijski kvocijent (eng. Cross-industry location quotient, CILQ) ublažava strogu pretpostavku promjene tehničkih koeficijenta samo po redovima te pretpostavlja da i sektori proizvođači i sektori potrošači mogu utjecati na sposobnost samoopskrbe regije. Flegg location quotient (FLQ) je modificirani CILQ s uključenom dodatnom mjerom relativne veličine regije (Flegg, Webber i Elliott, 1995; Flegg i Webber, 2000). Osim spomenutih varijanti lokacijskih kvocijenata za izradu RIO tablica, u primjenama su i razne modifikacije navedenih pristupa ovisno o usklađenosti podataka te željenog cilja analize.

Hibridni pristupi kombiniraju anketna istraživanja i istraživanja koja se ne temelje na anketama. U radu Lahr (1993) dan je pregled literature o hibridnim pristupima izrade RIO tablica. Jedna od hibridnih metoda je i GRIT (eng. Generation of Regional Input-Output Tables) metoda za izradu RIO tablica. GRIT metoda temelji se na nacionalnim IO tablicama i drugim izvorima podataka s mogućnošću umetanja dodatnih podataka u algoritam kako bi se poboljšala kvaliteta dobivenih rezultata, $\mathrm{tj}$. izradile realističnije RIO tablice (Jensen, Mandeville i Karunaratne, 1979; Deng, Wang, Wu, Zhang i Li, 2014).

Cilj ovog rada je procjena RIO tablicu za Hrvatsku u dvije regije: Kontinentalna i Jadranska Hrvatska. Takve RIO tablice prikazuju ne samo međusobna povezanost 
sektora u određenoj regiji, već i povezanost sa sektorima u drugim regijama. U nastavku je opisana metoda najpogodnija za izradu RIO tablica za Hrvatsku s obzirom na dostupnost podataka relevantnih za izradu RIO tablica. Izrada RIO tablica za Hrvatsku temeljena je na međusektorskim lokacijskim kvocijentima CILQ.

U CILQ pristupu uzima se u obzir važnost i sektora proizvođača i sektora potrošača kako u regiji tako i na nacionalnoj razini. Neka je $x_{i}^{r}$ output sektora $x_{i}^{n} \mathrm{u}$ regiji te neka je output sektora na nacionalnoj razini. CILQ lokacijski kvocijent definiran je na sljedeći način:

$$
\operatorname{CILQ}_{i j}^{r}=\frac{x_{i}^{r} / x_{i}^{n}}{x_{j}^{r} / x_{j}^{n}}
$$

Nadalje, neka $a_{i j}^{r r}$ označava regionalni koeficijent koji prikazuje input sektora $i$ u regiji $r$ po novčanoj jedinici outputa sektora $j$ u regiji $r$, te neka je $a_{i j}^{n}$ tehnički koeficijent na nacionalnoj razini. Tada je regionalni tehnički koeficijent $a_{i j}^{r}$, jednak

$$
a_{i j}^{r r}=\left\{\begin{array}{cc}
\operatorname{CILQ}_{i j}^{r} \cdot a_{i j}^{n}, & \text { ako je CILQ } \\
a_{i j}^{n}, & \text { ako je CILQ }
\end{array}\right.
$$

Dakle, ako je output regionalnog sektora $i$ u odnosu na output sektora $i$ nacionalnog gospodarstva veći od outputa regionalnog sektora $j \mathrm{u}$ odnosu na output sektora $j$ nacionalnog gospodarstva, tj. ako je $\mathrm{CILQ}_{i j}^{r}>1$, tada se sve potrebe sektora $j$ za inputima sektora $i$ mogu zadovoljiti unutar regije $r$. S druge strane, ako je ako je $\mathrm{CILQ}_{i j}^{r}<1$, tj. ako je output regionalnog sektora $i$ u odnosu na output sektora $i$ nacionalnog gospodarstva manji od outputa regionalnog sektora $j u$ odnosu na output sektora $j$ nacionalnog gospodarstva, tada regija $r$ nije u mogućnosti pokriti potrebe sektora $j$ za inputima sektora $i$ pa se određeni inputi trebaju uvesti iz drugih regija. Za $i=j, \mathrm{CILO}_{i i}^{r}=1$.

Nakon što su procijenjeni regionalni tehnički koeficijenti, tehnike IO analize koriste standardni instrumentarij temeljen na konceptu Leontijevljeve inverzne matrice $L=(I-A)^{-1}$ i izračuna multiplikatora (Oosterhaven i Stelder, 2007; Miller i Blair, 2009). Razlika je u tome što je kod primjene RIO tablice s dvije regije, matrica regionalnih tehničkih koeficijenata tipa $2 n \times 2 n$, gdje je $n$ broj proizvodnih sektora gospodarstva.

U konkretnom slučaju u ovom radu matrica regionalnih tehničkih koeficijenata ima 128 redaka i 128 stupaca. Prvi kvadrant matrice obuhvaća isporuke intermedijarnih inputa iz Kontinentalne Hrvatske za potrebe proizvodnje iste regije. Posljednji kvadrant prikazuje regionalne tehničke koeficijente za međusektorske isporuke unutar Jadranske regije. Drugi i treći segment matrice regionalnih tehničkih koeficijenata prikazuje međusektorske isporuke intermedijarnih inputa (Slika 1). 
Slika 1.

\section{LEONTIJEVLJEVI MULTIPLIKATORI U RIO TABLICAMA}

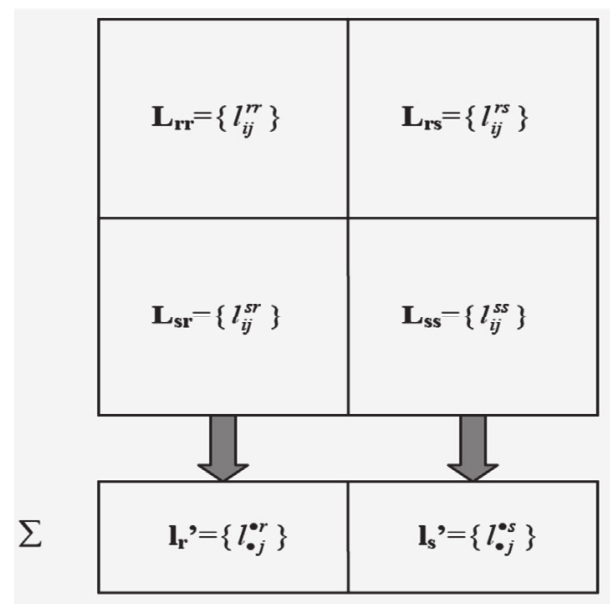

Izvor: Oosterhaven i Stelder (2007).

\section{REZULTATI}

U ovom poglavlju prikazuju se osnovni rezultati izračuna RIO tablica. Osnovni izračun pokazatelja iz skupa RIO tablica obuhvaća rezultate za 64 odjeljka ukupnog gospodarstva. U nastavku su rezultati opisani korištenjem sažetog prikaza na razini gospodarskih sektora, dok su najvažniji rezultati po odjeljcima prikazani u prilozima. Iako je Hrvatska nedavno odlučila promijeniti nomenklaturu statističkih NUTS 2 regija, statistički podaci za proteklo razdoblje dostupni su samo na po staroj nomenklaturi na razini dvije regije: Kontinentalna i Jadranska.

\subsection{Regionalna specijalizacija}

Gospodarska struktura u Kontinentalnoj i Jadranskoj Hrvatskoj značajno se razlikuje. Općenito se može zaključiti da je gospodarstvo Jadranske Hrvatske više koncentrirano (monokulturno) u odnosu na Kontinentalnu Hrvatsku, te je izrazito 
specijalizirano u sektoru koji obuhvaća trgovinu, prijevoz i ugostiteljstvo, sektor građevinarstva i poslovanja nekretninama (Tablica 1). Koeficijent specijalizacije pokazuje omjer udjela pojedine djelatnosti u bruto dodanoj vrijednosti (BDV) u pojedinoj regiji u odnosu na udio te djelatnosti u BDV-a u Hrvatskoj. Naravno, što je vrijednost koeficijenta veća od 1 , to je specijalizacija u pojedinoj djelatnosti izraženija. Vrijedi i obrnuto. Valja napomenuti da sektoru poslovanja nekretninama pripada i imputirana stambena renta, odnosno dohodak koji se imputira vlasnicima nekretnina koji u njima stanuju.

\section{Tablica 1 .}

UDIO POJEDINIH SEKTORA GOSPODARSTVA U BRUTO DODANOJ VRIJEDNOSTI (BDV) I REGIONALNI KOEFICIJENTI SPECIJALIZACIJE

\begin{tabular}{|l|l|r|r|r|r|r|}
\hline & & \multicolumn{3}{|c|}{ Udio u BDV, u \% } & \multicolumn{2}{|r|}{ Koeficijent specijalizacije } \\
\hline & & Hrvatska & Kontinentalna & Jadranska & Kontinentalna & Jadranska \\
\hline A & $\begin{array}{l}\text { Poljoprivreda, šumarstvo i } \\
\text { ribarstvo }\end{array}$ & 3,55 & 4,31 & 1,99 & 1,21 & 0,56 \\
\hline $\begin{array}{l}\text { B, C, } \\
\text { D, E }\end{array}$ & $\begin{array}{l}\text { Prerađivačka industrija, } \\
\text { rudarstvo i vađenje }\end{array}$ & 20,20 & 21,88 & 16,71 & 1,08 & 0,83 \\
\hline $\begin{array}{l}\text { od čega } \\
\text { C }\end{array}$ & Prerađivačka industrija & 15,62 & 17,29 & 12,18 & 1,11 & 0,78 \\
\hline F & Građevinarstvo & 5,04 & 4,24 & 6,70 & 0,84 & 1,33 \\
\hline G,H,I & $\begin{array}{l}\text { Trgovina, prijevoz i } \\
\text { skladištenje, smještaj, } \\
\text { usluživanje hrane }\end{array}$ & 23,16 & 19,84 & 30,05 & 0,86 & 1,30 \\
\hline J & Informacije i komunikacije & 4,80 & 6,02 & 2,26 & 1,26 & 0,47 \\
\hline K & $\begin{array}{l}\text { Financijske usluge i } \\
\text { osiguranje }\end{array}$ & 6,33 & 7,42 & 4,07 & 1,17 & 0,64 \\
\hline L & Poslovanje nekretninama & 9,49 & 7,83 & 12,92 & 0,83 & 1,36 \\
\hline M,N & $\begin{array}{l}\text { Stručne, znanstvene, } \\
\text { tehničke, administrativne i } \\
\text { pomoćne usluge }\end{array}$ & 8,42 & 9,01 & 7,19 & 1,07 & 0,85 \\
\hline O,P,Q & $\begin{array}{l}\text { Javna uprava i obrana, } \\
\text { obrazovanje, zdravstvo i } \\
\text { socijalna skrb }\end{array}$ & 15,30 & 15,97 & 13,91 & 1,04 & 0,91 \\
\hline R,S,T,U & Ostale uslužne djelatnosti & 3,72 & 3,48 & 4,21 & 0,94 & 1,13 \\
\hline
\end{tabular}

Izvor: izračun autora temeljem podataka DZS (https://www.dzs.hr/).

Kontinentalna Hrvatska je specijalizirana u proizvodnji poljoprivrednih i industrijskih proizvoda, informatičkim i komunikacijskim djelatnostima i finan- 
cijskim uslugama. Najmanje razlike u regionalnim udjelima zabilježene za javne usluge, obrazovanje, zdravstvo i socijalnu skrb. U načelu se može zaključiti da su u pogledu položaja u reprodukcijskom lancu, poduzetnici u Jadranskoj regiji više od prosjeka orijentirani na zadovoljavanje finalne osobne potrošnje bilo domaćih rezidenata, bilo potrošnje stranaca koji imaju značajan udio u ukupnoj finalnoj potrošnji proizvoda koje isporučuje sektor trgovine, prijevoza i ugostiteljstva. Stoga je ova regija i osjetljivija na eksterne šokove vezane uz pojavu koronavirusa, a koji dovode do smanjenja potražnje za uslugama veznim uz transport, turizam i različite kategorije osobnih usluga.

Podaci o regionalnoj specijalizaciji na detaljnijoj razini (razina odjeljaka) prikazani su u prilogu (Prilog 1). Koeficijent specijalizacije veći od 1,3 Kontinentalna Hrvatska ostvaruje u proizvodnji poljoprivrednih proizvoda, prerađivačkoj industriji visoke tehnološke razine (proizvodnja računala, električne opreme i strojeva), zračnom transportu, proizvodnji filmova i zapisa, istraživanju i razvoju, te promidžbenim uslugama. Jadranska Hrvatska specijalizirana je u ribarstvu, proizvodnji ostalih prijevoznih sredstava (brodogradnja), popravku i instaliranju strojeva i opreme, komunalnim uslugama, građevinarstvu, smještaju i usluživanja hrane i pića, uslugama putničkih agencija, uslugama iznajmljivanja i imputiranoj stambenoj renti. U pogledu tehnološke strukture može se uočiti da u Jadranskoj Hrvatskoj veći udio imaju proizvodi niže tehnološke razine, s izuzetkom proizvodnje prijevoznih sredstava.

\subsection{Regionalne input-output tablice}

Prema metodologiji opisanoj u prethodnom poglavlju, RIO tablice konstruirane su na razini 64 odjeljka nacionalnog gospodarstva za 2017. godinu. Budući takvu matricu nije bilo moguće prikazati u cjelovitom obliku, u Tablici 2 je dan sažet prikaz za pojedine sektore nacionalnog gospodarstva označene slovima od A do U po regijama. Kont označava Kontinentalnu Hrvatsku, a Jadr Jadransku Hrvatsku. Najznačajniji indikatori koji proizlaze iz primjene IO analize detaljnije su prikazani u prilozima na kraju rada. 
Ž. LOVRINČEVIĆ, D. MIKULIĆ, D. KEČEK: Izlazna gospodarska strategija Hrvatske u vrijeme pandemije COVID-19... EKONOMSKI PREGLED, 72 (3) 449-485 (2021)

Tablica 2 .

\section{SAŽETI PRIKAZ RIO TABLICE, U MILIJUNIMA HRK}

\begin{tabular}{|l|r|r|r|r|r|r|r|r|r|r|}
\hline & Kont_A & Kont_B-E & Kont_F-I & Kont_J-U & Jadr_A & Jadr_B-E & Jadr_F-I & Jadr_J-U & $\begin{array}{c}\text { Finalne } \\
\text { isporuke }\end{array}$ & $\begin{array}{c}\text { Ukupne } \\
\text { isporuke }\end{array}$ \\
\hline Kont_A & 2478 & 4480 & 668 & 150 & 307 & 1873 & 309 & 41 & 7059 & 17365 \\
\hline Kont_B-E & 1736 & 23751 & 15905 & 10741 & 128 & 2261 & 6224 & 1554 & 49972 & 112272 \\
\hline Kont_F-I & 1144 & 10867 & 19407 & 7321 & 166 & 1026 & 3105 & 560 & 89344 & 132940 \\
\hline Kont_J-U & 694 & 7094 & 16160 & 26628 & 116 & 1060 & 4067 & 2612 & 97363 & 155794 \\
\hline Jadr_A & 45 & 126 & 57 & 8 & 654 & 687 & 159 & 25 & 2698 & 4458 \\
\hline Jadr_B-E & 375 & 1432 & 451 & 556 & 309 & 7599 & 5753 & 3120 & 23508 & 43102 \\
\hline Jadr_F-I & 247 & 1492 & 2006 & 978 & 224 & 3688 & 9206 & 2929 & 62999 & 83770 \\
\hline Jadr_J-U & 126 & 425 & 670 & 1547 & 124 & 1900 & 5301 & 7962 & 48394 & 66449 \\
\hline Uvoz & 1859 & 22536 & 13117 & 9160 & 361 & 8024 & 7962 & 4325 & 113780 & 181123 \\
\hline Neto porezi & 515 & 887 & 2301 & 4063 & 63 & 340 & 1415 & 1752 & 52432 & 63767 \\
\hline BDV & 8147 & 39182 & 62198 & 94643 & 2007 & 14645 & 40268 & 41569 & & \\
\hline Output & 17365 & 112272 & 132940 & 155794 & 4458 & 43102 & 83770 & 66449 & 547550 & 861040 \\
\hline
\end{tabular}

Izvor: izračun autora.

Svaki redak Tablice 2 prikazuje strukturu isporuka određenog sektora gospodarstva i određene regije, drugim proizvodnim sektorima (iste, ali i druge regije) za potrebe intermedijarne potrošnje, te finalne isporuke (osobna i državna potrošnja, investicije i izvoz). Tako prvi redak (Kont-A) prikazuje da sektor poljoprivrede, šumarstva i ribarstva od ukupne proizvodnje vrijednosti 17,4 milijardi kuna (sjecište prvog retka i posljednjeg stupca tablice) za potrebe finalne potražnje isporučuje proizvoda vrijednosti 7,1 milijardu kuna, dok 10,3 milijardi kuna predstavlja intermedijarnu potrošnju drugih poduzetnika podijeljenih u osam skupina (po četiri sektora u svakoj od regija).

Za razliku od redaka, stupci u tablici pokazuju troškovnu strukturu vrijednosti proizvodnje za svaki od sektora. Tako od ukupne vrijednosti proizvodnje poljoprivrednih proizvoda 17,4 milijardi kuna 9,3 milijardi kuna čini intermedijarna potrošnja, a 8,1 milijarde kuna BDV. Intermedijarna potrošnja obuhvaća potrošnju sirovina, materijala i proizvodnih usluga koje su isporučili domaći sektori (također razdvojeno na 4 sektora u dvije regije), uvoz intermedijarnih proizvoda i neto poreze koji su uključeni u vrijednost intermedijarnih inputa. Slika 2 prikazuje vrijednosnu strukturu isporuka pojedinih sektora. 
Slika 2.

VRIJEDNOSNA STRUKTURA ISPORUKA POJEDINIH SEKTORA

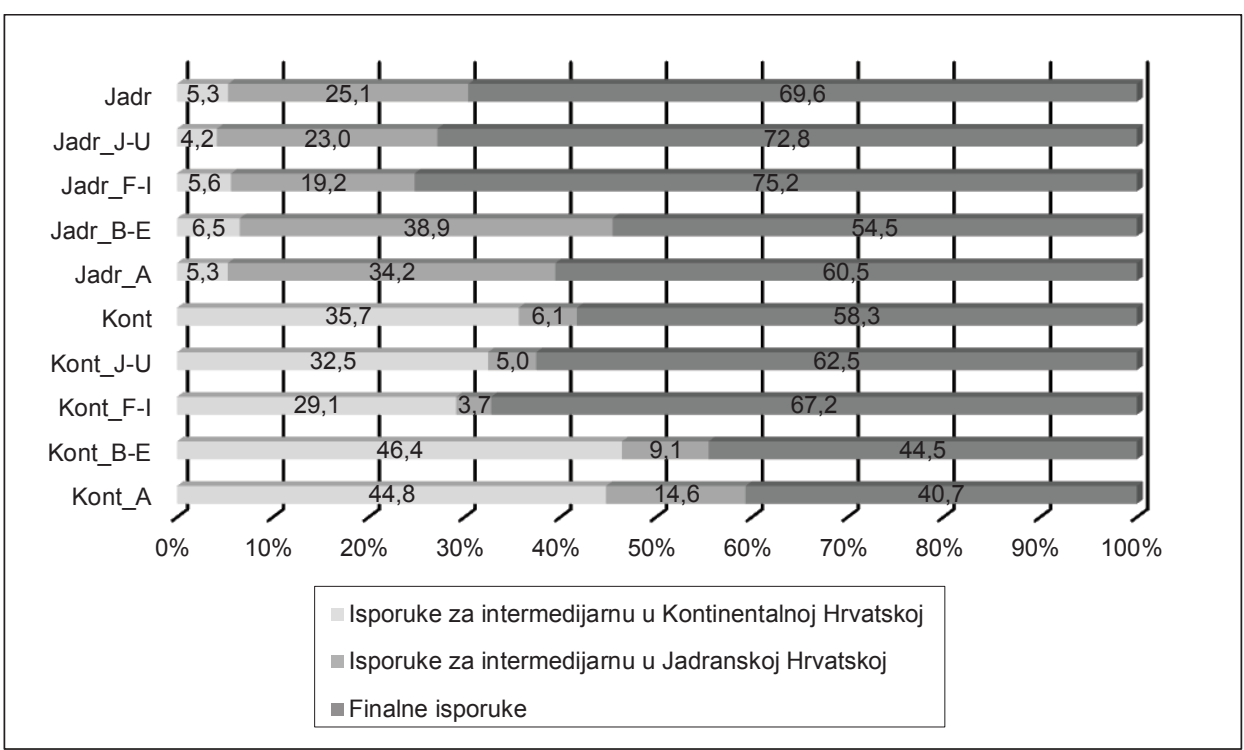

Izvor: izračun autora.

Može se uočiti da ukupno gospodarstvo Kontinentalne Hrvatske u prosjeku isporučuje 58,3\% proizvodnje za finalne isporuke (u koje je uključen ukupan izvoz bez obzira da li je riječ moguće o intermedijarnim proizvodima koje naručuju inozemni proizvođači). Taj pokazatelj je značajno veći za Jadransku Hrvatsku i iznosi čak 69,6 \%. Udio isporuka za finalne isporuke prikazuje ujedno značaj strukture za prikupljanje potrošnih poreza jer finalne isporuke čine uglavnom većinu porezne osnovice. To je posebice značajno kod turizma. Općenito se za obje regije može zaključiti da kad je riječ o proizvodnji fizičkih dobara (poljoprivreda i industrija) u pravilu je veći udio isporuka za potrebe intermedijarne potrošnje poduzetnika u istoj ili drugoj regiji, dok uslužne djelatnosti veći obujam outputa isporučuju finalnim potrošačima. Kontinentalna Hrvatska ima veći udio isporuka namijenjenih intermedijarnoj potrošnji i proizvođačima u istoj regiji $(35,7 \%$, dok je takav pokazatelj za Jadransku Hrvatsku 25,1 \%) i proizvođačima u drugoj regiji. Kontinentalna Hrvatska je u tom smislu samodostatnija glede intermedijarne potrošnje, a veza između dvije regije je izrazito slaba to ukazuje na činjenicu da većina inputa za Jadransku Hrvatsku stiže iz uvoza. Još je slabija veza između inputa koje Jadranska Hrvatska osigurava za isporuke za intermedijarnu potrošnju 
Ž. LOVRINČEVIĆ, D. MIKULIĆ, D. KEČEK: Izlazna gospodarska strategija Hrvatske u vrijeme pandemije COVID-19... EKONOMSKI PREGLED, 72 (3) 449-485 (2021)

u Hrvatskoj i iznosi samo 5,3\% ukupnih isporuka iz regije Jadranska Hrvatska. Kontinentalna Hrvatska isporučuje prosječno 6,1 \% vlastite proizvodnje za intermedijarnu potrošnju u Jadranskoj Hrvatskoj. Strukturna povezanost dviju regije je izrazito slaba, te ukazuje na mogućnost da šok izazvan epidemijom COVID-19 bude vrlo asimetričan na način da je puno izraženiji u Jadranskoj Hrvatskoj uz istovremeno značajan utjecaj na prihode državnog proračuna zbog visokog udjela finalnih isporuka u Jadranskoj Hrvatskoj.

\subsection{Međuregionalne isporuke dobara i usluga}

RIO tablica omogućuje praćenje međusobne povezanosti hrvatskih regija. Valja napomenuti da primijenjena metodologija omogućuje praćenje međuregionalnih isporuka u neto iskazu. Za regiju koja čiji je indeks specijalizacije niži $\mathrm{u}$ odnosu na nacionalni prosjek, odnosno proizvodi ispodprosječan obujam proizvoda u nekom sektoru, pretpostavlja se da dio dobara i usluga nabavlja od druge regije. Ukupna vrijednost trgovine može biti veća u slučaju da postoje i intrasektorske isporuke. Tablica 3 prikazuje procijenjenu vrijednost razmjene intermedijarnih inputa i dobara za osobnu potrošnju po sektorima nacionalnog gospodarstva u 2017. godini, dok je detaljnija raščlamba po odjeljcima prikazana u Prilogu 2. na kraju rada. Razlike u strukturnim karakteristikama gospodarstva rezultiraju značajno višim iznosom isporuka intermedijarnih dobara iz Kontinentalne u Jadransku Hrvatsku, dok je obrnut slučaj zabilježen u pogledu isporuka dobara i usluga namijenjenih osobnoj potrošnji. Suficit Kontinentalne Hrvatske najveći je upravo u sektorima u kojima je indeks specijalizacije najveći, poput poljoprivrede i prerađivačke industrije. U prosjeku se proizvođači iz Jadranske Hrvatske nalaze bliže krajnjeg potrošaču, te su im u proizvodnim procesima potrebni inputi koji se ne proizvode u dovoljnoj mjeri u vlastitoj regiji. Međutim, takvi pokazatelji znače da će u slučaju smanjenja finalne potražnje u Jadranskoj Hrvatskoj negativne učinke osjetiti i svi proizvođači u reprodukcijskom lancu, a od kojih je dio i u Kontinentalnoj Hrvatskoj. 
Tablica 3.

MEĐUREGIONALNE ISPORUKE INTERMEDIJARNIH PROIZVODA I PROIZVODA ZA OSOBNU POTROŠNJU, U MILIJUNIMA HRK

\begin{tabular}{|l|r|r|r|r|r|r|}
\hline & \multicolumn{2}{|c|}{$\begin{array}{c}\text { Međuregionalne } \\
\text { isporuke } \\
\text { intermedijarnih } \\
\text { proizvoda }\end{array}$} & \multicolumn{2}{c|}{$\begin{array}{c}\text { Isporuke za osobnu } \\
\text { potrošnju }\end{array}$} & \multicolumn{2}{c|}{$\begin{array}{c}\text { Ukupno } \\
\text { međuregionalne } \\
\text { isporuke }\end{array}$} \\
\hline & $\begin{array}{c}\text { Iz Kont. u } \\
\text { Jadr. }\end{array}$ & $\begin{array}{c}\text { Iz Jadr. u } \\
\text { Kont. }\end{array}$ & $\begin{array}{c}\text { Iz Kont. u } \\
\text { Jadr. }\end{array}$ & $\begin{array}{c}\text { Iz Jadr. u } \\
\text { Kont. }\end{array}$ & $\begin{array}{c}\text { Iz Kont. u } \\
\text { Jadr }\end{array}$ & $\begin{array}{c}\text { Iz Jadr.. u } \\
\text { Kont. }\end{array}$ \\
\hline A & 2.530 & 236 & 1.524 & 300 & 4.053 & 535 \\
\hline B,C,D,E & 10.168 & 2.813 & 838 & 1.530 & 11.006 & 4.344 \\
\hline od čega C & 8.050 & 1.781 & 754 & 1.414 & 8.804 & 3.195 \\
\hline F & 231 & 1.342 & 0 & 14 & 231 & 1.356 \\
\hline G,H,I & 4.626 & 3.381 & 1.968 & 1.783 & 6.595 & 5.164 \\
\hline J & 1.757 & 45 & 987 & 0 & 2.744 & 45 \\
\hline K & 2.003 & 132 & 1.321 & 0 & 3.323 & 132 \\
\hline L & 491 & 719 & 0 & 3.705 & 491 & 4.424 \\
\hline M,N & 3.155 & 1.569 & 141 & 268 & 3.296 & 1.837 \\
\hline O,P,Q & 174 & 101 & 155 & 0 & 329 & 101 \\
\hline R,S,T,U & 276 & 202 & 0 & 208 & 276 & 410 \\
\hline & $\mathbf{2 5 . 4 1 0}$ & $\mathbf{1 0 . 5 4 0}$ & $\mathbf{6 . 9 3 3}$ & $\mathbf{7 . 8 0 8}$ & $\mathbf{3 2 . 3 4 3}$ & $\mathbf{1 8 . 3 4 8}$ \\
\hline
\end{tabular}

Izvor: izračun autora.

Za razliku od intermedijarne potražnje, Jadranska Hrvatska ostvaruje suficit u razmjeni dobara i usluga za finalnu potrošnju. Zanimljivo je primijetiti da je kod osobne potrošnje ostvaren suficit na razini cijele prerađivačke industrije. Međutim, kao što tablica iz priloga pokazuje, riječ je o suficitu koji je primarno ostvaren u odjeljku prehrambenih proizvoda uključujući pića i duhan (1368 milijuna HRK). Detaljnije analize pokazuje da je to zapravo primarno posljedica razmjene duhanskim proizvodima čija se glavnina proizvodnje odvija u Jadranskoj Hrvatskoj (Kanfanar). Zanimljivo je primijetiti i da gotovo 50\% izvoza dobara i usluga iz Jadranske u Kontinentalnu Hrvatsku čini sektor L, odnosno imputirana stambena renta. Riječ je o računovodstvenoj kategoriji, a ne stvarnim novčanim tokovima. Naime, prema načelima nacionalnih računa, aktivnost „,proizvodnje“ imputiranih usluga stanovanja bilježi se na lokaciji gdje se nekretnina nalazi, bez 
Ž. LOVRINČEVIĆ, D. MIKULIĆ, D. KEČEK: Izlazna gospodarska strategija Hrvatske u vrijeme pandemije COVID-19... EKONOMSKI PREGLED, 72 (3) 449-485 (2021)

obzira na prebivalište vlasnika nekretnine. Dio kuća i stanova duž Jadranske obale u vlasništvu je rezidenata Kontinentalne Hrvatske takve usluge zapravo troše rezidenti Kontinentalne Hrvatske usprkos činjenici da je proizvodnja zabilježena u Jadranskoj Hrvatskoj.

\subsection{Multiplikatori proizvodnje, bruto dodane vrijednosti i učinci pora- sta finalne potražnje na zaposlenost po regijama}

Korištenjem formula iz metodološkog dijela između kojih je ključan koncept Leontijevljeve inverzne matrice možemo izračunati multiplikatore outputa, bruto dodane vrijednosti i zaposlenosti, kao i ukupne učinke jedinične promjene finalne potražnje na BDV i zaposlenost. U slučaju primjene RIO tablice s dvije regije, ukupna matrica ima redaka i stupaca, gdje je broj proizvodnih sektora. Zbrajanjem učinaka po stupcima (recima) koji se odnose na odgovarajuću regiju (prvih 64 se odnose na Kontinentalnu Hrvatsku) možemo učinke porasta finalne potražnje za proizvodima jedne regije razdvojiti na induciranu BDV i zaposlenost za svaku od regija.

Izračun učinaka porasta finalne potražnje za proizvodima koji se proizvode u Kontinentalnoj Hrvatskoj prikazan je Tablicom 4. Prvi redak pokazuje učinke porasta finalne potražnje za proizvodima poljoprivrede, šumarstva i ribarstva koje isporučuju poduzetnici iz Kontinentalne Hrvatske. Multiplikator outputa za ovaj sektor iznosi 1,76 što znači da ako finalna potražnja poraste za 1 jedinicu, osim vrijednosti isporuke jedinice koje isporučuje taj finalni output (1), radi potrebe za nabavkama intermedijarnih inputa, ostali hrvatski proizvođači povećat će vrijednost outputa za još dodatnih 0,76 jedinica. Ista interpretacija vrijedi i za multiplikatore BDV i zaposlenosti. Ukupni učinci na BDV u slučaju jediničnog porasta potražnje za poljoprivrednim proizvodima za Kontinentalnu Hrvatsku iznose 0,82, od čega će BDV u Kontinentalnoj Hrvatskoj porasti za 0,74 jedinica, a BDV u Jadranskoj za 0,07 jedinica. Učinci na zaposlenost iskazani su u terminima porasta finalne potražnje vrijednosti 1 milijun kuna. Na primjeru istog sektora može se uočiti da porast zaposlenosti induciran porastom finalne potražnje za poljoprivrednim proizvodima, vrijednosti 1 milijun kuna iznosi 5,9 zaposlenika u Kontinentalnoj i dodatnih 0,41 zaposlenika u Jadranskoj Hrvatskoj. Za razliku od nacionalnih input-output tablica, regionalne tablice omogućuju ocjenu intenziteta regionalne povezanosti u pojedinim proizvodim procesima. Što su učinci na BDV i zaposlenost u drugoj regiji veći, to je veći i intenzitet međuregionalne integracije proizvodnog procesa. 
Tablica 4 .

\section{MULTIPLIKATORI OUTPUTA, TE REGIONALNI UČINCI JEDINIČNOG PORASTA FINALNE POTRAŽNJE ZA PROIZVODIMA KOJE ISPORUČUJU PODUZETNICI U KONTINENTALNOJ HRVATSKOJ NA BDV I ZAPOSLENOSTI}

\begin{tabular}{|c|c|c|c|c|c|c|c|c|c|}
\hline & & $\begin{array}{l}\text { Mult. } \\
\text { output }\end{array}$ & $\begin{array}{l}\text { Mult } \\
\text { BDV }\end{array}$ & $\begin{array}{l}\text { Multi } \\
\text { zap. }\end{array}$ & $\mathrm{BDV}$ & $\begin{array}{l}\text { BDV } \\
\text { Kont. }\end{array}$ & $\begin{array}{l}\text { BDV } \\
\text { Jadr. }\end{array}$ & $\begin{array}{l}\text { Zap. } \\
\text { Kont. }\end{array}$ & $\begin{array}{l}\text { Zap. } \\
\text { Jadr. }\end{array}$ \\
\hline A & $\begin{array}{l}\text { Poljoprivreda, šumarstvo i } \\
\text { ribarstvo }\end{array}$ & 1,76 & 1,74 & 1,54 & 0,82 & 0,74 & 0,07 & 5,90 & 0,41 \\
\hline $\mathrm{B}, \mathrm{C}, \mathrm{D}, \mathrm{E}$ & $\begin{array}{l}\text { Prerađivačka industrija, } \\
\text { rudarstvo i vađenje }\end{array}$ & 1,72 & 1,91 & 1,89 & 0,67 & 0,64 & 0,03 & 3,25 & 0,16 \\
\hline od čega $C$ & Prerađivačka industrija & 1,74 & 1,96 & 1,88 & 0,65 & 0,62 & 0,04 & 3,35 & 0,18 \\
\hline $\mathrm{F}$ & Građevinarstvo & 1,85 & 1,97 & 1,73 & 0,74 & 0,72 & 0,03 & 4,17 & 0,14 \\
\hline $\mathrm{G}, \mathrm{H}, \mathrm{I}$ & $\begin{array}{c}\text { Trgovina, prijevoz i } \\
\text { skladištenje, smještaj, } \\
\text { usluživanje hrane }\end{array}$ & 1,69 & 1,80 & 1,86 & 0,79 & 0,76 & 0,03 & 3,92 & 0,16 \\
\hline $\mathrm{J}$ & Informacije i komunikacije & 1,68 & 1,65 & 1,96 & 0,84 & 0,80 & 0,04 & 2,80 & 0,17 \\
\hline K & Financijske usluge i osiguranje & 1,52 & 1,52 & 1,57 & 0,89 & 0,87 & 0,02 & 2,98 & 0,11 \\
\hline $\mathrm{L}$ & Poslovanje nekretninama & 1,35 & 1,27 & 1,54 & 0,91 & 0,90 & 0,01 & 1,66 & 0,04 \\
\hline $\mathrm{M}, \mathrm{N}$ & $\begin{array}{c}\begin{array}{c}\text { Stručne, znanstvene, tehničke, } \\
\text { administrativne i pomoćne } \\
\text { usluge }\end{array} \\
\end{array}$ & 1,58 & 1,58 & 1,59 & 0,81 & 0,77 & 0,03 & 3,83 & 0,17 \\
\hline $\mathrm{O}, \mathrm{P}, \mathrm{Q}$ & $\begin{array}{c}\text { Javna uprava i obrana, } \\
\text { obrazovanje, zdravstvo i } \\
\text { socijalna skrb } \\
\end{array}$ & 1,42 & 1,34 & 1,22 & 0,84 & 0,83 & 0,01 & 6,15 & 0,07 \\
\hline $\mathrm{R}, \mathrm{S}, \mathrm{T}, \mathrm{U}$ & Ostale uslužne djelatnosti & 1,47 & 1,46 & 1,38 & 0,84 & 0,82 & 0,01 & 5,82 & 0,06 \\
\hline
\end{tabular}

Izvor: izračun autora.

Općenito se iz ukupnih multiplikatora može zaključiti da sektori koji proizvode fizičke proizvode (poljoprivreda, prerađivačka industrija, građevinarstvo) u pravilu zbog primjene složenijih proizvodnih procesa imaju i veće multiplikativne učinke. Međutim, zbog višeg udjela BDV u outputu kod uslužnih sektora kod kojih je visoka radna intenzivnost, ukupni učinci na BDV i zaposlenost su ipak nešto izraženiji. U slučaju mjera ekonomske politike koji stimuliraju proizvodnju u uslužnim sektorima, učinci na BDV i zaposlenost se u prosjeku manje šire na ostale sektore i regije, već je većina takvih učinaka ograničena na regiju i sektor koji se stimulira. S druge strane, povećanje finalne potražnje za poljoprivrednim proizvodima i proizvodima prerađivačke industrije, te graditeljstva ima intenzivnije neizravne učinke na ostatak 
gospodarstva. Te djelatnosti bi trebale činiti osnovicu poticanja gospodarstva u izlaznoj strategiji Hrvatske tijekom pandemije. U prosjeku se može zaključiti da proizvodni procesi u Kontinentalnoj Hrvatskoj zahtijevaju ograničenu količinu inputa iz Jadranske Hrvatske, te se i učinci porasta finalne potražnje u toj regiji putem kanala intermedijarne potražnje slabo odražavaju na Jadransku regiju.

Ukupni učinci porasta finalne potražnje u Jadranskoj Hrvatskoj na BDV i zaposlenost prikazani su Tablicom 5. Zbog primijenjenih pretpostavki o istoj tehnologiji proizvodnje u obje regije, multiplikatori po djelatnostima se ne razlikuju, ali se razlikuju učinci na pojedine regije. Može se ocijeniti da su poduzetnici iz Kontinentalne Hrvatske više uključeni u proizvodne procese proizvođača u Jadranskoj regiji, te porast finalne potražnje u Jadranskoj regiji potiče i aktivnost određenih sektora Kontinentalne regije.

\section{Tablica 5 .}

MULTIPLIKATORI OUTPUTA, TE REGIONALNI UČINCI JEDINIČNOG PORASTA FINALNE POTRAŽNJE ZA PROIZVODIMA KOJE ISPORUČUJU PODUZETNICI U JADRANSKOJ HRVATSKOJ NA BDV I ZAPOSLENOSTI

\begin{tabular}{|c|c|c|c|c|c|c|c|c|c|}
\hline & Mult. & $\begin{array}{c}\text { Mult } \\
\text { Output }\end{array}$ & $\begin{array}{c}\text { Multi } \\
\text { zap. }\end{array}$ & BDV & $\begin{array}{c}\text { BDV } \\
\text { Kont. }\end{array}$ & $\begin{array}{c}\text { BDV } \\
\text { Jadr. }\end{array}$ & $\begin{array}{c}\text { Zap. } \\
\text { Kont. }\end{array}$ & $\begin{array}{c}\text { Zap. } \\
\text { Jadr. }\end{array}$ \\
\hline A & $\begin{array}{c}\text { Poljoprivreda, šumarstvo i } \\
\text { ribarstvo }\end{array}$ & 1,76 & 1,74 & 1,60 & 0,82 & 0,15 & 0,67 & 0,95 & 5,08 \\
\hline od čega C & $\begin{array}{c}\text { Prerađivačka industrija, } \\
\text { rudarstvo i vađenje }\end{array}$ & 1,72 & 1,93 & 1,91 & 0,66 & 0,09 & 0,57 & 0,43 & 3,21 \\
\hline F & $\begin{array}{c}\text { Prerađivačka industrija } \\
\text { Građevinarstvo }\end{array}$ & 1,74 & 1,99 & 1,93 & 0,65 & 0,09 & 0,56 & 0,45 & 3,27 \\
\hline G, H, I & $\begin{array}{c}\text { Trgovina, prijevoz i } \\
\text { skladištenje, smještaj, } \\
\text { usluživanje hrane }\end{array}$ & 1,69 & 1,77 & 1,84 & 0,80 & 0,12 & 0,68 & 0,54 & 3,76 \\
\hline $\mathrm{J}$ & $\begin{array}{c}\text { Informacije i komunikacije } \\
\mathrm{K}\end{array}$ & 1,68 & 1,64 & 1,78 & 0,83 & 0,09 & 0,75 & 0,31 & 3,43 \\
\hline $\mathrm{F}$ & Financijske usluge i osiguranje & 1,52 & 1,52 & 1,63 & 0,89 & 0,05 & 0,84 & 0,18 & 3,03 \\
\hline Poslovanje nekretninama & 1,35 & 1,27 & 1,55 & 0,91 & 0,08 & 0,83 & 0,30 & 1,44 \\
\hline M, N & $\begin{array}{c}\text { Stručne, znanstvene, tehničke, } \\
\text { administrativne i pomoćne } \\
\text { usluge }\end{array}$ & 1,58 & 1,58 & 1,45 & 0,80 & 0,07 & 0,73 & 0,28 & 4,76 \\
\hline O, P, Q & $\begin{array}{c}\text { Javna uprava i obrana, } \\
\text { obrazovanje, zdravstvo i } \\
\text { socijalna skrb }\end{array}$ & 1,42 & 1,33 & 1,21 & 0,84 & 0,06 & 0,78 & 0,26 & 6,38 \\
\hline R, S, T, U & Ostale uslužne djelatnosti & 1,47 & 1,46 & 1,41 & 0,83 & 0,08 & 0,75 & 0,36 & 6,86 \\
\hline
\end{tabular}

Izvor: izračun autora. 
Tako primjerice porast finalne potražnje vrijednosti 1 milijun kuna usluga trgovine, transporta i ugostiteljstva u Jadranskoj Hrvatskoj pored 680 tisuća kuna BDV, odnosno 3,76 radnih mjesta ostvarenih u Jadranskoj Hrvatskoj inducira i 120 tisuća kuna BDV, odnosno 0,54 radnih mjesta u Kontinentalnoj Hrvatskoj. Slični pokazatelji vrijede i za sektore poljoprivrede i građevinarstva dok je međuregionalno prelijevanje aktivnosti za ostale sektore nešto manje izraženo. Detaljniji podaci koji se odnose na učinke procijenjene za pojedine odjeljke prikazani su u Prilozima 3. i 4.

\subsection{Regionalna distribucija BDV i zaposlenost inducirana finalnom potražnjom u Kontinentalnoj i Jadranskoj Hrvatskoj}

Korištenjem RIO tablica i strukturnih karakteristika gospodarstva, ukupna se BDV i zaposlenost svake od regija može dekomponirati na učinke finalne potražnje $u$ Kontinentalnoj i Jadranskoj Hrvatskoj. Prvi stupac Tablice 6 prikazuje finalnu potražnju za dobrima i uslugama koje isporučuju poduzetnici iz Kontinentalne Hrvatske.

Tablica 6.

UKUPNA BDV I ZAPOSLENOST INDUCIRANA FINALNOM POTRAŽNJOM ZA DOBRIMA I USLUGAMA KOJE ISPORUČUJU PROIZVOĐAČI IZ KONTINENTALNE HRVATSKE, U MILIJUNIMA HRK

\begin{tabular}{|l|r|r|r|r|r|r|r|}
\hline & $\begin{array}{c}\text { Finalna } \\
\text { potražnja }\end{array}$ & $\begin{array}{c}\text { Ukupna } \\
\text { BDV }\end{array}$ & $\begin{array}{c}\text { BDV } \\
\text { Kont. }\end{array}$ & $\begin{array}{c}\text { BDV } \\
\text { Jadr. }\end{array}$ & $\begin{array}{c}\text { Ukupna } \\
\text { zaposlenost }\end{array}$ & $\begin{array}{c}\text { Zap. } \\
\text { Kont. }\end{array}$ & $\begin{array}{c}\text { Zap. } \\
\text { Jadr. }\end{array}$ \\
\hline A & 7059 & 6656 & 6509 & 147 & 69543 & 68504 & 1039 \\
\hline B,C,D,E & 49972 & 35534 & 34289 & 1246 & 185647 & 180144 & 5502 \\
\hline od čega C & 44570 & 26735 & 26058 & 678 & 160365 & 156808 & 3556 \\
\hline F & 20138 & 11471 & 10820 & 652 & 74765 & 71373 & 3392 \\
\hline G,H,I & 69206 & 49670 & 47816 & 1855 & 275378 & 264906 & 10472 \\
\hline J & 7436 & 8222 & 8164 & 58 & 20239 & 20030 & 208 \\
\hline K & 8789 & 11916 & 11738 & 178 & 29288 & 28897 & 391 \\
\hline L & 15126 & 16200 & 15767 & 433 & 16153 & 14623 & 1530 \\
\hline M,N & 7472 & 15856 & 14909 & 948 & 73537 & 68486 & 5052 \\
\hline O,P,Q & 49517 & 31417 & 31340 & 77 & 215870 & 215243 & 627 \\
\hline R,S,T,U & 9023 & 6015 & 5897 & 118 & 37532 & 36853 & 679 \\
\hline Ukupno & 243738 & 192958 & 187247 & 5711 & 997951 & 969058 & 28893 \\
\hline Prosječno na 1 mil HRK & 1 & 0,792 & 0,768 & 0,023 & 4,094 & 3,976 & 0,119 \\
\hline
\end{tabular}

Izvor: izračun autora. 
Zadovoljavanjem finalne potražnje od 243 milijardi kuna, poduzetnici iz Kontinentalne Hrvatske ostvaruju oko 187 milijardi kuna BDV pritom zapošljavajući 969 tisuća osoba. Zbog primjene proizvodnih procesa koji zahtijevaju određene inpute iz Jadranske Hrvatske, porasti će BDV i zaposlenost i u toj regiji. Međutim, može se uočiti da porast finalne potražnje u Kontinentalnoj Hrvatskoj prosječno vrlo slabo inducira porast ekonomske aktivnosti u Jadranskoj Hrvatskoj. Tako na 1 milijun HRK finalne potražnje u Kontinentalnoj regiji od ukupnog porasta BDV u Hrvatskoj u iznosu od 792 tisuće HRK, tek se 23 tisuće kuna ostvaruje u Jadranskoj regiji.

Međuregionalno prelijevanje učinaka iz Jadranske u Kontinentalnu Hrvatsku nešto je intenzivnije. U prosjeku 1 milijun kuna finalne potražnje za proizvodima koju isporučuju poduzetnici u Jadranskoj Hrvatskoj inducira 674 milijuna kuna BDV u toj regiji dok se 123 milijuna kuna ostvaruje u Kontinentalnoj Hrvatskoj. Učinak regionalnog rasprostiranja finalne potražnje na zaposlenost također je veći u Jadranskoj Hrvatskoj.

\section{Tablica 7.}

\section{UKUPNA BDV I ZAPOSLENOST INDUCIRANA FINALNOM POTRAŽNJOM ZA DOBRIMA I USLUGAMA KOJE ISPORUČUJU PROIZVOĐAČI IZ JADRANSKE HRVATSKE, U MILIJUNIMA HRK}

\begin{tabular}{|l|c|c|c|c|c|c|c|}
\hline & $\begin{array}{c}\text { Finalna } \\
\text { potražnja }\end{array}$ & $\begin{array}{c}\text { Ukupna } \\
\text { BDV }\end{array}$ & $\begin{array}{c}\text { BDV } \\
\text { Kont. }\end{array}$ & $\begin{array}{c}\text { BDV } \\
\text { Jadr. }\end{array}$ & $\begin{array}{c}\text { Ukupna } \\
\text { zaposlenost }\end{array}$ & $\begin{array}{c}\text { Zap. } \\
\text { Kont. }\end{array}$ & $\begin{array}{c}\text { Zap. } \\
\text { Jadr. }\end{array}$ \\
\hline A & 2698 & 3498 & 1638 & 1860 & 32612 & 17546 & 15066 \\
\hline B,C,D,E & 23508 & 18293 & 4893 & 13399 & 86324 & 23398 & 62926 \\
\hline od čega C & 19758 & 13013 & 3480 & 9533 & 69232 & 20138 & 49094 \\
\hline F & 12525 & 6825 & 260 & 6565 & 35891 & 1715 & 34176 \\
\hline G,H,I & 50475 & 34500 & 3303 & 31197 & 195978 & 17321 & 178657 \\
\hline J & 1939 & 3060 & 1353 & 1706 & 9084 & 3110 & 5974 \\
\hline K & 2962 & 5312 & 1875 & 3437 & 12539 & 4128 & 8410 \\
\hline L & 13016 & 13073 & 549 & 12524 & 9579 & 1883 & 7696 \\
\hline M,N & 3993 & 8061 & 2640 & 5421 & 45968 & 12504 & 33464 \\
\hline O,P,Q & 21000 & 13374 & 197 & 13176 & 102417 & 1375 & 101042 \\
\hline R,S,T,U & 5485 & 3708 & 215 & 3493 & 23763 & 1393 & 22371 \\
\hline Ukupno & 137600 & 109702 & 16924 & 92778 & 554154 & 84372 & 469782 \\
\hline $\begin{array}{l}\text { Prosječno na 1 } \\
\text { mil HRK }\end{array}$ & 1 & 0,797 & 0,123 & 0,674 & 4,027 & 0,613 & 3,414 \\
\hline
\end{tabular}

Izvor: izračun autora. 
Ukupno se oko 17 milijardi kuna uz angažman 84,3 tisuće zaposlenika ostvaruje kod poduzetnika u Kontinentalnoj Hrvatskoj, a temeljem isporuke intermedijarnih dobara i usluga koje koriste poduzetnici u Jadranskoj Hrvatskoj u svojim proizvodnim procesima. Najznačajniji učinak odnosi se na induciranu aktivnost sektora prerađivačke industrije, trgovine i stručnih, znanstvenih i ostalih poslovnih usluga.

Ukoliko se ukupna BDV ostvarena na teritoriju pojedine regije dekomponira na BDV induciran finalnom potražnjom iz iste, odnosno druge regije možemo dobiti pokazatelj intenziteta uključenosti pojedine regije u proizvodne procese druge regije. Takvi udjeli prikazani su na Slici 3.

Slika 3.

\section{UDIO BDV POJEDINE REGIJE KOJI JE INDUCIRAN POTRAŽNJOM} IZ DRUGE REGIJE

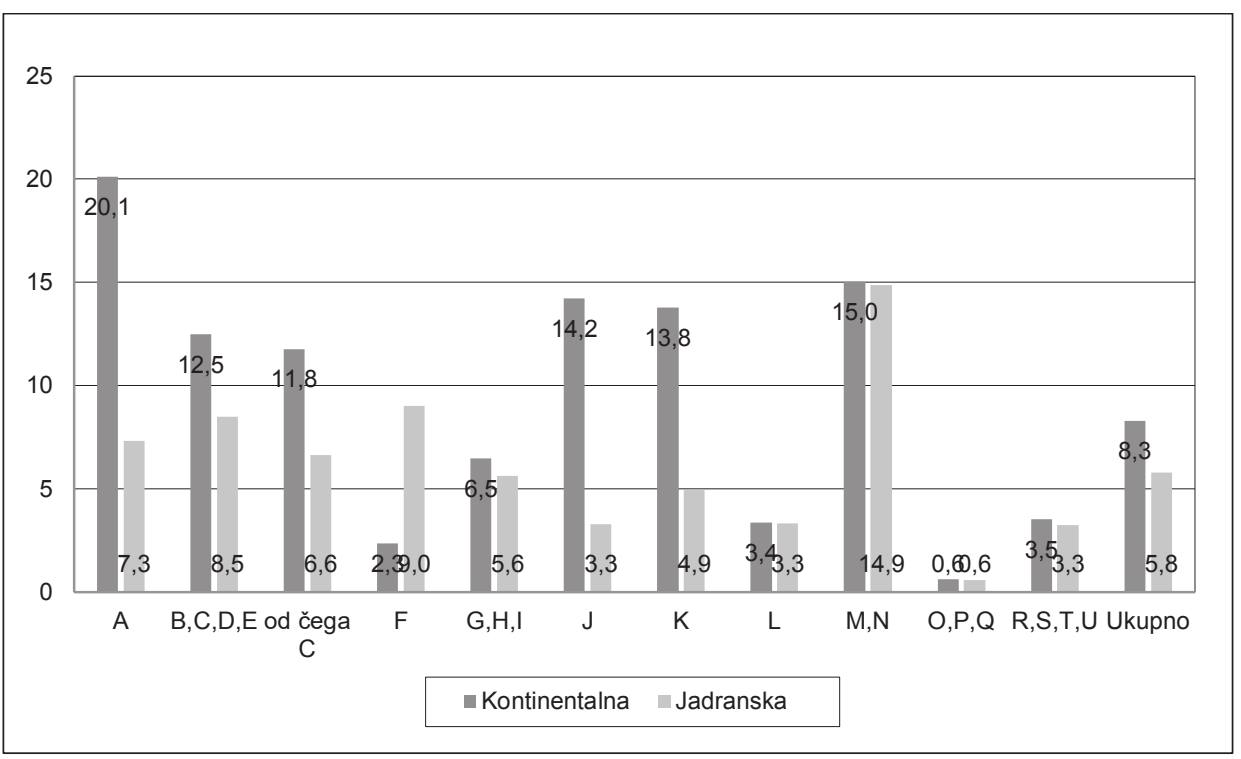

Izvor: izračun autora.

I pokazatelj udjela BDV pojedine regije koji je induciran finalnom potražnjom druge regije ukazuje na veću razinu uključenosti poduzetnika iz Kontinentalne Hrvatske u proizvodne procese poduzetnika u Jadranskoj Hrvatskoj. U prosjeku je oko $8,3 \%$ BDV-a Kontinentalne regije induciran potražnjom iz druge regije, dok 
je samo 5,8 \% BDV-a Jadranske regije inducirano potražnjom iz Kontinentalne Hrvatske. Najveća razina proizvodne integriranosti regija zabilježena je za sektor M, N koji obuhvaća stručne, znanstvene, tehničke, administrativne i pomoćne usluge, dok je očekivano najniža razina integracije u sektoru javnih usluga. Značaj potražnje iz Jadranske regije za Kontinentalnu regiju je najveći kod poljoprivrede (A) i pokazuje da je 20,1\% BDV-a ostvarenog u poljoprivredi Kontinentalne Hrvatske generirano potražnjom iz Jadranske Hrvatske. Integriranost poduzetnika iz Kontinentalne Hrvatske veća je kod svih proizvodnih sektora izuzev građevinarstva. Slika 3. ukazuje na situaciju izuzetno malene integriranosti dviju regija u cjelini jer se većina uvoza u regiju Jadranska Hrvatska za potrebe turizma i pratećih djelatnosti ne generira iz regije Kontinentalna Hrvatska, već iz uvoza.

\section{ZAKLJUČAK}

Standardni ekonomski modeli u kojima se dugoročni rad temelji na rastu proizvodnih faktora rada i kapitala, te ostvareni BDP oscilira oko potencijalnog, a razlike u uspješnosti pojedinih zemalja ovise o efikasnosti i produktivnosti u korištenju faktora nije upotrebljiv u uvjetima pojave intenzivnih eksternih šokova poput pandemije COVID-19. Recentna literatura ukazuje na pojavu negativne spirale između pada potražnje i ponude koja može rezultirati uspostavom nove ravnoteže tek na vrlo niskoj razini ekonomske aktivnosti (Fornaro i Wolf, 2020), a koja ne osigurava dostatna sredstva za održavanje standarda kućanstava ni održavanje funkcioniranja javnog sektora, a posebno zdravstvenog sustava u srednjem roku. Stoga sve više radova ukazuje na potrebu formuliranja izlazne strategije (Anderson, Mckee i Mossialos, 2020; Loayza i Pennings, 2020; Europska komisija, 2020) koja bi obuhvaćala skup aktivnijih mjera ekonomske politike kojima bi se osiguralo pokretanje gospodarstva nakon što se u određenoj mjeri umanje ograničenja vezana uz socijalno distanciranje. Pravila Europske unije o razini deficita i duga javnog sektora i zabrani potpora koje narušavaju funkcioniranje slobodnog tržišta također se u uvjetima zdravstvene ugroze i zatvaranja granica nužno prilagođavaju i zemljama se na raspolaganju stavlja nešto fleksibilniji instrumentarij monetarne i fiskalne politike. Intenzitet učinaka i brzina širenja stimulansa monetarne i fiskalne politike u velikoj mjeri ovisi o zatečenoj gospodarskoj strukturi, međusektorskim i međuregionalnim proizvodnim odnosima. Mjere usmjerene na sektore koji imaju veće multiplikativne učinke kako u pogledu sektorskih učinaka, tako i regionalnih rezultirat će bržim oporavkom gospodarstva.

RIO tablice prikazuju najveće multiplikativne učinke za sektore koji proizvode fizičke proizvode poput poljoprivrede, prerađivačke industrije i građevinarstva, 
dok su indirektni učinci u uslužnom sektoru, posebice turizmu plitki zbog slabe povezanosti dviju regija. Analiza je ukazala da su poduzetnici iz Kontinentalne Hrvatske više uključeni u lance dodane vrijednosti Jadranske Hrvatske, dok je struktura gospodarstva Jadranske Hrvatske više temeljena na uslužnim djelatnostima namijenjenim finalnoj potražnji. Veći udio finalnih isporuka nalazi se upravo u Jadranskoj Hrvatskoj, te će COVID-19 pandemija imati veći utjecaj na javne financije i proračun, nego na pad gospodarstva u cjelini. Elastičnost proračunskog salda u odnosu na kretanje BDP-a je očito veća od jedinice. Pad potražnje i ograničenja u aktivnostima uslužnih djelatnosti stoga će više pogoditi Jadransku regiju, dok će s druge strane učinak smanjenja inozemne potražnje i međunarodne razmjene više utjecati na poduzetnike iz Kontinentalne regije, a posebice sektore koji ostvaruju značajan robni izvoz.

Za sada je nepoznato koliko dugo će trajati opasnost od širenja virusa, ali može se očekivati da će određene mjere ograničenja socijalnih kontakata trajati sve do vremena u kojem će u upotrebi biti učinkovito cjepivo. Stoga posebnu pozornost treba posvetiti formuliranju specifičnih mjera za pojedine sektore jer fiskalni prostor javnih financija nije neograničen. Određeni sektori gospodarstva kod kojih se aktivnost može se uz određene mjere opreza odvijati na dosadašnji način bez velikih rizika za širenje virusa, a istovremeno imaju velik multiplikativni učinak, trebali bi postati nositelji oporavka. Kako je uglavnom riječ o poljoprivredi, industriji i građevinarstvo koji imaju visoke multiplikativne učinke, poticanje ovih aktivnosti daje pozitivne rezultate već u kratkom roku, a pozitivni poticaj širi se i na ostale djelatnosti i regije. Osim ovih djelatnosti naglasak treba biti i na unapređivanju sektora zdravstva i sektora informacijsko-komunikacijskih tehnologija, kod kojih su neizravni gospodarski učinci nešto niži, ali koji će biti ključni za nesmetano odvijanje gospodarske aktivnosti u budućem razdoblju.

Definiranje skupa mjera mora uzeti u obzir specifičnosti pojedinih sektora. Imajući u vidu potrebe za sanacijom posljedica nedavnog potresa u Zagrebu, što brži početak radova na obnovi objekata vjerojatno je najbolji pristup za pokretanje građevinske aktivnosti. Dok će sufinanciranje obnove stambenih objekata $u$ privatnom vlasništvu zahtijevati određeno vrijeme za definiranje modela i stupnja nepovratnih sredstava, izravno investiranje u obnovu oštećenih škola, bolnica i drugih javnih zgrada može početi vrlo brzo. Osim obnove Zagreba, u drugim područjima država može povećati intenzitet energetske obnove javnih zgrada ili povećati raspoloživi iznos za energetsku obnovu stambenih objekata. Investicije u obnovu zgrada potaknut će i cijeli niz potpornih aktivnosti poput proizvodnje građevinskog materijala, stolarije i slično. Održavanje kapaciteta graditeljstva je nužno i za realizaciju nastavka projekata sufinanciranim EU sredstvima. Određeni napori trebali bi biti usmjereni i na otklanjanje eventualnih uskih grla u proizvodnji potrebnih materijala imajući u vidu smanjenu dobavljivost uvoznih proizvoda. 
Značajan potencijal u oporavku ima poljoprivredno-prehrambeni klaster. U ovom klasteru trebalo bi formulirati širi skup mjera s ciljem aktiviranja nekorištenog zemljišta i kapaciteta za proizvodnju ratarskih i stočarskih proizvoda i njihovu preradu u industrijskim postrojenjima. Dostupnost kvalitetne i zdravstveno sigurne hrane još će više dobiti na značaju u budućem razdoblju te neizvjesnost oko dužine trajanja pandemije i ograničenja koja uvode ostale zemlje na izvoz strateških poljoprivrednih proizvoda. U program poticaja osim samih proizvođača hrane, trebalo bi uključiti i niz potpornih sektora, od proizvodnje gnojiva i stočne hrane do skladištenja i veterinarskih usluga.

Izvozno orijentirani sektori zahtijevaju drugačiji pristup u odnosu na mjere poticanja aktivnosti i izravnih investicija. Pad inozemne potražnje za fizičkim proizvodima vjerojatno će se dijelom ublažiti nakon što prođe najintenzivnija faza socijalnog distanciranja u zemljama koje su najvažniji partneri. U suradnji s najvećim izvoznicima trebalo bi definirati najpovoljniji način održavanja barem minimalne razine proizvodnje za različite sektore do razdoblja u kojem će se uspostaviti suradnja s ranijim trgovačkim partnerima.

Skupina uslužnih djelatnosti u kojoj je mogućnost socijalnog distanciranja manja (osobne usluge, kozmetičke usluge, ugostiteljstvo i slične djelatnosti) zahtijevat će primjenu različitih procedura zaštite čime će se način pružanja takvih usluga značajno modificirati, barem u srednjoročnom razdoblju. Ukoliko takvo razdoblje potraje, troškovi vezani uz primjenu sigurnosnih procedure rezultirat će uspostavom nove razine cijena takvih usluga na višoj razini od trenutne, a kojom će se kompenzirati smanjenje obujma takvih usluga. Uloga države trebala bi biti u potporama za sufinanciranje investicija potrebnih za očuvanje zdravstvene sigurnosti (nabavka pregrada ili zdravstvene opreme), dok porast intermedijarnih troškova (sredstava za dezinfekciju, povećani jedinični trošak energije i slično), pružatelji takvih usluga trebaju prenijeti na finalne potrošače. Poseban problem povezan s epidemijom Covid-19 odnosi se na snažno smanjivanje broja turističkih dolazaka, a što će posebice negativno utjecati na gospodarstvo Jadranske regije. Kako potrošnja inozemnih turista čini i više od 85 posto ukupnih turističkih prihoda, doseg politike poticanja domaće turističke potražnje je više nego ograničen, posebice u uvjetima kad je razina cijena smještaja u kvalitetnim objektima nepriuštiva za domaćeg potrošača. Dosadašnja porezna politika koja je poticala izgradnju brojnih apartmana i drugih turističkih objekata rezultirala je prevladavajućim konceptom masovnog turizma koji je nužno transformirati. Pored negativnih eksternalija u pogledu ugrožavanja okoliša i komunalnog preopterećenja u dosadašnjem razdoblju, nova situacija podrazumijeva i rizik potencijalnih troškova zdravstvenog sustava koji mogu biti i veći od ostvarenih turističkih prihoda. Dok u slučaju smještaja i pružanja ugostiteljskih usluga postoje određeni multiplikativni učinci koji se šire na ostale proizvodne sektore i regije, neizravni učinci kod iznajmljivanja stambenog prostora gotovo ne postoje, te 
je teško opravdati intervenciju države u definiranje poticaja za takav skup aktivnosti. Hotelski kompleksi, kampovi i restorani mogu se u određenoj mjeri prilagoditi na način da povećanim mjerama zaštite i unapređenjem kvalitete usluge uz smanjeni obujam usluga povećaju cijene smještaja. Razvitak situacije u ovom sektoru će bitno ovisiti o relaksiranju prekogranične slobode kretanja građana u okviru EU, što će biti vrlo dugotrajan i spor proces. Ishod takvog procesa će u velikoj mjeri ovisiti o svim članicama EU gdje će jedan dio zemalja, emitivnih turističkih tržišta za Hrvatsku, nastojati zadržati potražnju za uslugama putovanja na domaćem tržištu u uvjetima recesije. Stoga treba i mjere zadržavanja postojeće zaposlenosti na vrijeme prilagoditi, na način da tržište počinje igrati sve značajniju ulogu. Država ne bi trebala administrativnim ograničenjima pokušavati predugo održavati zaposlenost u onim sektorima koji nemaju značajan multiplikativan učinak na cjelokupno gospodarstvo ili gdje zbog objektivnih okolnosti nije moguće kompenzirati pad inozemne potražnje. Time bi samo odgodila neizbježno, te dodatno smanjila ionako ograničen, a nužan prostor za fiskalne poticaje u gospodarstvu.

\section{LITERATURA}

1. Anderson, M., Mckee, M. i Mossialos, E. (2020). Developing a sustainable exit strategy for COVID-19:health, economic and public policy implications. Journal of the Royal Society of Medicine, 113(5), 176-178. DOI: $10.1177 / 0141076820925229$

2. Boero, R., Edwards, B. K. i Rivera, M. K. (2018). Regional input-output tables and trade flows: an integrated and interregional non-survey approach. Regional Studies, 52(2), 225-238.

3. Bonfiglio, A. i Chelli, F. (2008). Assessing the behaviour of nonsurvey methods for constructing regional input-output tables through a Monte Carlo simulation. Economic Systems Research, 20, 243-258. DOI:10.1080/09535310802344315.

4. Buturac, G., Mikulić, D. i Palić, P. (2019). Sources of export growth and development of manufacturing industry: empirical evidence from Croatia. Ekonomska istraživanja, 32(1), 101-127. DOI:10.1080/1331677x.2018.1550003

5. Deng, X., Wang, Y., Wu, F., Zhang, T. i Li, Z. (2014). Integrated River Basin Management. Springer-Verlag Berlin Heidelberg. DOI: 10.1007/978-3-66243466-6.

6. Europska komisija. (2020). Joint statement of the Members of the European Council. Dostupno na https://www.consilium.europa.eu/media/43076/26-vceuco-statement-en.pdf 
7. Fernandes, N. (2020). Economic Effects of Coronavirus Outbreak (COVID-19) on the World Economy (March 22, 2020). Dostupno na https://ssrn.com/abstract=3557504 ili http://dx.doi.org/10.2139/ssrn.3557504

8. Flegg, A. T. i Tohmo, T. (2013). Regional input-output tables and the FLQ formula: A case study of Finland. Regional Studies, 47, 703-721. DOI: 10.1080/00343404.2011.592138

9. Flegg, A. T., Webber, C. D. i Elliott, M. V. (1995). On the Appropriate Use of Location Quotients in Generating Regional Input-Output Tables. Regional Studies, 29(6), 547-561.

10. Flegg, A. T. i Webber, C. D. (2000). Regional size, regional specialization and the FLQ formula. Regional Studies, 34, 563-569.

11. Fornaro, L. i Wolf, M. (2020). COVID-19 Coronavirus and Macroeconomic Policy (March 2020). CEPR Discussion Paper No. DP14529. Dostupno na https://ssrn.com/abstract=3560337

12. Ivandić, N. i Šutalo, I. (2018). The contribution of tourism to the Croatian economy: an IO approach. Ekonomski pregled, 69(1), 20-42.

13. Jensen, R. C., T. D. Mandeville i N. D. Karunaratne. (1979). Regional economic planning. London: Croom Helm.

14. Keček, (2019). Alternativni model izoliranja sektora u input- output sustavu: metodološki pristup i primjena na hrvatski IKT sector. Ekonomski pregled, 70(3), 431-450.

15. Keček, D., Boljunčić, V. i Mikulić, D. (2019). Hypothetical extraction approach for measuring total economic effects of Croatian ICT sector. Croatian operational research review, 10(1), 131-140. DOI:10.17535/ crorr.2019.0012.

16. Keček, D., Mikulić, D. i Lovrinčević, Ž. (2019). Deployment of renewable energy: economic effects on the Croatian economy. Energy policy, 126, 402410. DOI:10.1016/j.enpol.2018.11.028

17. Lahr, M. (1993). A Review of the Literature Supporting the Hybrid Approach to Constructing Regional Input-Output Models. Economic Systems Research, 5(3), 277-293.

18. Loayza, N. V. i Pennings, S. (2020). Macroeconomic Policy in the Time of COVID-19: A Primer for Developing Countries. Research \& Policy Briefs From the World Bank Malaysia Hub, 1-9. Dostupno na https://elibrary.worldbank.org/doi/pdf/10.1596/33540

19. Mikulić, D. (2018). Osnove input-output analize s primjenom na hrvatsko gospodarstvo. Zagreb: Ekonomski institut. 
20. Mikulić, D., Keček, D. i Žajdela Hrustek, N. (2017). Overall contribution of the foreign tourist demand on Croatian economy. Tourism and Creative Industries: Trends and Challenges, Opatija, Hrvatska, 393-407. DOI:10.20867/tosee.04.11

21. Mikulić, D., Lovrinčević, Ž. i Keček, D. (2018). Economic effects of wind power plant deployment on the Croatian economy. Energies, 11(7); 1881. DOI:10.3390/en11071881

22. Mikulić, D., Slijepčević, S. i Buturac, G. (2020). Energy renovation of multi apartment buildings: Contributions to economy and climate changes, Energy and buildings, 224, 110247. DOI:10.1016/j.enbuild.2020.110247

23. Miller, R. E., Blair, P. D. (2009). Input-Output Analysis: Foundations and Extensions. New York: Cambridge University Press.

24. Okamoto, N. i Ihara, T. (2005). Spatial Structure and Regional Development in China - An Interregional Input-Output Approach. Palgrave MacMillan.

25. Oosterhaven, J. i Polenske, K. R. (2009). Modern regional input-output analyses. In Capello R and Nijkamp P. Handbook of regional growth and development theories. Edward Elgar.

26. Oosterhaven, J. i Stelder, D. (2007). Regional and Interregional IO Analysis. Dostupno na https://www.rug.nl/research/reg/research/irios/download/regional-io-analysis.pdf

27. Semerak, V., Zigic, K., Loizou, E. i Golemanova-Kuhar, A. (2010). Regional input-output analysis: application on rural regions in Germany, the Czech Republic and Greece. 118th Seminar, August 25-27, 2010, Ljubljana, Slovenia 94904, European Association of Agricultural Economists. DOI: 10.22004/ag.econ.94904

28. Sixta, J. (2017). Input-Output Approach to Regional Employment. Statistika, 97(1), 5-17.

29. Szabó, N. (2015). Methods for regionalizing input-output tables. Regional Statistics, 5(1), 44-65. DOI: 10.15196/RS05103.

30. ten Raa, T. (2005). The Economics of Input-Output Analysis. Cambridge: Cambridge Univeristy Press

31. Vltavská K. i Fischer J. (2017). Macroeconomic Impact of Expenditures on Higher Education: Regional Input-Output Analysis. Journal on Efficiency and Responsibility in Education and Science, 10(4), 116-120. DOI: 10.7160/eriesj.2017.100404.

32. Vltavská, K. i Sixta, J. (2017). Input-Output Tables for Regions of the Czech Republic. Statistika, 97(2), 4-14. 
Ž. LOVRINČEVIĆ, D. MIKULIĆ, D. KEČEK: Izlazna gospodarska strategija Hrvatske u vrijeme pandemije COVID-19.. EKONOMSKI PREGLED, 72 (3) 449-485 (2021)

33. United Nations. (2018). Handbook on Supply, Use and Input-Output Tables with Extensions and Applications Department of Economic and Social Affairs. Statistics Division, Series F No.74, Rev.1.

\section{PRILOG 1.}

\section{Udio pojedinih odjeljaka gospodarstva u BDV i regionalni koeficijenti specijalizacije}

\begin{tabular}{|c|c|c|c|c|c|c|}
\hline & & \multicolumn{3}{|c|}{ Udio u BDV } & \multicolumn{2}{|c|}{$\begin{array}{c}\text { Koeficijent } \\
\text { specijalizacije }\end{array}$} \\
\hline & & Hrvatska & Kontinentalna & Jadranska & Hrvatska & Kontinentalna \\
\hline A01 & Poljoprivreda i lov & 2,72 & 3,67 & 0,74 & 1,35 & 0,27 \\
\hline A02 & Šumarstvo & 0,53 & 0,61 & 0,37 & 1,15 & 0,69 \\
\hline $\mathrm{A} 03$ & Ribarstvo & 0,31 & 0,03 & 0,89 & 0,08 & 2,90 \\
\hline B & Rudarstvo & 0,39 & 0,47 & 0,21 & 1,21 & 0,55 \\
\hline $\mathrm{C} 10-\mathrm{C} 12$ & $\begin{array}{l}\text { Prehrambeni proizvodi pića; } \\
\text { duhan }\end{array}$ & 3,64 & 3,18 & 4,59 & 0,87 & 1,26 \\
\hline C13-C15 & Tekstil; odjeća; koža & 0,81 & 1,11 & 0,20 & 1,36 & 0,25 \\
\hline C16 & $\begin{array}{l}\text { Drvo i pluto, osim } \\
\text { namještaja }\end{array}$ & 0,66 & 0,84 & 0,29 & 1,27 & 0,43 \\
\hline $\mathrm{C} 17$ & Papir & 0,24 & 0,30 & 0,12 & 1,24 & 0,49 \\
\hline $\mathrm{C} 18$ & $\begin{array}{l}\text { Tiskanje i umnožavanje } \\
\text { snimljenih zapisa }\end{array}$ & 0,46 & 0,54 & 0,30 & 1,17 & 0,64 \\
\hline $\mathrm{C} 19$ & Rafinirani naftni proizvodi & 1,41 & 1,62 & 0,97 & 1,15 & 0,69 \\
\hline $\mathrm{C} 20$ & Kemikalije & 0,40 & 0,53 & 0,13 & 1,33 & 0,31 \\
\hline $\mathrm{C} 21$ & Farmaceutski proizvod & 0,90 & 1,23 & 0,20 & 1,37 & 0,22 \\
\hline $\mathrm{C} 22$ & Guma i plastika & 0,63 & 0,68 & 0,52 & 1,09 & 0,82 \\
\hline $\mathrm{C} 23$ & $\begin{array}{l}\text { Ostali nemetalni mineralni } \\
\text { proizvodi }\end{array}$ & 0,86 & 0,81 & 0,98 & 0,93 & 1,14 \\
\hline $\mathrm{C} 24$ & Metal & 0,15 & 0,14 & 0,16 & 0,97 & 1,06 \\
\hline $\mathrm{C} 25$ & Gotovi metalni proizvodi & 1,89 & 2,18 & 1,29 & 1,15 & 0,68 \\
\hline $\mathrm{C} 26$ & $\begin{array}{l}\text { Računala, elektronički i } \\
\text { optički proiz. }\end{array}$ & 0,59 & 0,79 & 0,17 & 1,34 & 0,29 \\
\hline $\mathrm{C} 27$ & Električna oprema & 0,72 & 0,97 & 0,20 & 1,35 & 0,28 \\
\hline $\mathrm{C} 28$ & Strojevi i uređaji & 0,70 & 0,94 & 0,21 & 1,34 & 0,30 \\
\hline $\mathrm{C} 29$ & Motorna vozila i prikolice & 0,13 & 0,11 & 0,18 & 0,83 & 1,35 \\
\hline $\mathrm{C} 30$ & Ostala prijevozna sredstva & 0,22 & 0,09 & 0,48 & 0,43 & 2,18 \\
\hline
\end{tabular}




\begin{tabular}{|c|c|c|c|c|c|c|}
\hline & & \multicolumn{3}{|c|}{ Udio u BDV } & \multicolumn{2}{|c|}{$\begin{array}{c}\text { Koeficijent } \\
\text { specijalizacije }\end{array}$} \\
\hline & & Hrvatska & Kontinentalna & Jadranska & Hrvatska & Kontinentalna \\
\hline C31_C32 & $\begin{array}{l}\text { Namještaj; Ostala } \\
\text { prerađivačka industrija }\end{array}$ & 0,60 & 0,70 & 0,40 & 1,16 & 0,67 \\
\hline C33 & $\begin{array}{l}\text { Popravak i instaliranje } \\
\text { strojeva i opreme }\end{array}$ & 0,61 & 0,51 & 0,80 & 0,84 & 1,32 \\
\hline $\mathrm{D}$ & $\begin{array}{l}\text { Opskrba električnom } \\
\text { energijom, plinom, parom }\end{array}$ & 2,82 & 2,92 & 2,61 & 1,04 & 0,93 \\
\hline E36 & $\begin{array}{l}\text { Skupljanje, pročišćavanje i } \\
\text { opskrba vodom }\end{array}$ & 0,61 & 0,56 & 0,72 & 0,92 & 1,17 \\
\hline E37-E39 & $\begin{array}{l}\text { Uklanjanje otpadnih voda; } \\
\text { zbrinjavanje otpada }\end{array}$ & 0,75 & 0,64 & 0,99 & 0,85 & 1,31 \\
\hline $\mathrm{F}$ & Građevinarstvo & 5,04 & 4,24 & 6,70 & 0,84 & 1,33 \\
\hline G45 & $\begin{array}{l}\text { Trgovina na veliko i na malo } \\
\text { motornim vozilima }\end{array}$ & 1,12 & 1,28 & 0,79 & 1,14 & 0,71 \\
\hline G46 & $\begin{array}{l}\text { Trgovina na veliko, osim } \\
\text { motornim vozilima }\end{array}$ & 5,42 & 6,31 & 3,56 & 1,17 & 0,66 \\
\hline G47 & $\begin{array}{l}\text { Trgovina na malo, osim } \\
\text { trgovine motornim vozilima }\end{array}$ & 5,41 & 4,98 & 6,28 & 0,92 & 1,16 \\
\hline H49 & $\begin{array}{l}\text { Kopneni prijevoz i } \\
\text { cjevovodni transport }\end{array}$ & 2,26 & 2,61 & 1,55 & 1,15 & 0,69 \\
\hline $\mathrm{H} 50$ & Vodeni prijevoz & 0,47 & 0,01 & 1,43 & 0,02 & 3,03 \\
\hline H51 & Zračni prijevoz & 0,12 & 0,16 & 0,03 & 1,36 & 0,25 \\
\hline H52 & $\begin{array}{l}\text { Skladištenje i prateće } \\
\text { djelatnosti u prijevozu }\end{array}$ & 1,21 & 1,06 & 1,54 & 0,87 & 1,27 \\
\hline H53 & $\begin{array}{l}\text { Poštanske i kurirske } \\
\text { djelatnosti }\end{array}$ & 0,55 & 0,54 & 0,57 & 0,98 & 1,03 \\
\hline I & $\begin{array}{l}\text { Smještaj i usluživanja hrane } \\
\text { i pića }\end{array}$ & 6,59 & 2,88 & 14,28 & 0,44 & 2,17 \\
\hline J58 & Izdavačke djelatnosti & 0,34 & 0,39 & 0,24 & 1,14 & 0,70 \\
\hline J59_J60 & $\begin{array}{l}\text { Filmovi, TV program, } \\
\text { snimanje zvučnih zapisa }\end{array}$ & 0,60 & 0,78 & 0,22 & 1,31 & 0,36 \\
\hline J61 & Telekomunikacije & 1,96 & 2,48 & 0,88 & 1,27 & 0,45 \\
\hline J62_J63 & $\begin{array}{l}\text { Računalno programiranje, } \\
\text { savjetovanje }\end{array}$ & 1,90 & 2,36 & 0,92 & 1,25 & 0,49 \\
\hline K64 & $\begin{array}{l}\text { Financijske uslužne } \\
\text { djelatnosti, osim osiguranja }\end{array}$ & 4,87 & 5,70 & 3,13 & 1,17 & 0,64 \\
\hline K65 & $\begin{array}{l}\text { Osiguranje, reosiguranje i } \\
\text { mirovinski fondovi }\end{array}$ & 0,69 & 0,81 & 0,44 & 1,17 & 0,64 \\
\hline K66 & Pomoćne financijske usluge & 0,77 & 0,91 & 0,50 & 1,17 & 0,64 \\
\hline L68A & Poslovanje nekretninama & 2,27 & 2,20 & 2,41 & 0,97 & 1,06 \\
\hline L68B & Imputirana renta & 7,22 & 5,64 & 10,50 & 0,78 & 1,45 \\
\hline
\end{tabular}


Ž. LOVRINČEVIĆ, D. MIKULIĆ, D. KEČEK: Izlazna gospodarska strategija Hrvatske u vrijeme pandemije COVID-19... EKONOMSKI PREGLED, 72 (3) 449-485 (2021)

\begin{tabular}{|c|c|c|c|c|c|c|}
\hline & & \multicolumn{3}{|c|}{ Udio u BDV } & \multicolumn{2}{|c|}{$\begin{array}{c}\text { Koeficijent } \\
\text { specijalizacije }\end{array}$} \\
\hline & & Hrvatska & Kontinentalna & Jadranska & Hrvatska & Kontinentalna \\
\hline M69_M70 & $\begin{array}{l}\text { Pravne i računovodstvene } \\
\text { usluge }\end{array}$ & 2,66 & 2,99 & 1,97 & 1,13 & 0,74 \\
\hline M71 & $\begin{array}{l}\text { Arhitektonske djelatnosti i } \\
\text { inženjerstvo }\end{array}$ & 1,71 & 1,72 & 1,69 & 1,01 & 0,99 \\
\hline M72 & $\begin{array}{l}\text { Znanstveno istraživanje i } \\
\text { razvoj }\end{array}$ & 0,72 & 0,93 & 0,27 & 1,30 & 0,38 \\
\hline M73 & $\begin{array}{l}\text { Promidžba i istraživanje } \\
\text { tržišta }\end{array}$ & 0,50 & 0,69 & 0,11 & 1,37 & 0,23 \\
\hline $\mathrm{N}$ & $\begin{array}{l}\text { Ostale stručne, znanstvene i } \\
\text { tehničke usluge }\end{array}$ & 0,37 & 0,45 & 0,22 & 1,20 & 0,59 \\
\hline N77 & $\begin{array}{l}\text { Iznajmljivanje i davanje u } \\
\text { zakup (leasing) }\end{array}$ & 0,74 & 0,55 & 1,12 & 0,75 & 1,52 \\
\hline N78 & Djelatnosti zapošljavanja & 0,45 & 0,54 & 0,27 & 1,19 & 0,61 \\
\hline N79 & \begin{tabular}{|l}
$\begin{array}{l}\text { Putničke agencije, } \\
\text { organizatori putovanja }\end{array}$ \\
\end{tabular} & 0,38 & 0,21 & 0,74 & 0,54 & 1,95 \\
\hline N80-N82 & $\begin{array}{l}\text { Zaštitne i istražne usluge; } \\
\text { Administrativne usluge }\end{array}$ & 0,89 & 0,94 & 0,78 & 1,06 & 0,88 \\
\hline 0 & $\begin{array}{l}\text { Javna uprava i obrana; } \\
\text { obvezno soc. osiguranje }\end{array}$ & 5,29 & 5,41 & 5,02 & 1,02 & 0,95 \\
\hline $\mathrm{P}$ & Obrazovanje & 4,99 & 5,17 & 4,61 & 1,04 & 0,93 \\
\hline Q86 & Zdravstvena zaštita & 4,34 & 4,65 & 3,68 & 1,07 & 0,85 \\
\hline Q87_Q88 & Socijalna skrb & 0,69 & 0,74 & 0,59 & 1,07 & 0,85 \\
\hline R90-R92 & $\begin{array}{l}\text { Kreativne, umjetničke i } \\
\text { zabavne djelatnosti }\end{array}$ & 1,21 & 1,09 & 1,46 & 0,90 & 1,21 \\
\hline R93 & $\begin{array}{l}\text { Sportske i rekreacijske } \\
\text { djelatnosti }\end{array}$ & 0,76 & 0,68 & 0,92 & 0,90 & 1,21 \\
\hline S94 & $\begin{array}{l}\text { Djelatnosti članskih } \\
\text { organizacija }\end{array}$ & 0,61 & 0,60 & 0,63 & 0,98 & 1,03 \\
\hline S95 & $\begin{array}{l}\text { Popravak računala i } \\
\text { predmeta za osobnu uporabu }\end{array}$ & 0,19 & 0,19 & 0,20 & 0,98 & 1,03 \\
\hline S96 & $\begin{array}{l}\text { Ostale osobne uslužne } \\
\text { djelatnosti }\end{array}$ & 0,90 & 0,89 & 0,93 & 0,98 & 1,03 \\
\hline $\mathrm{T}$ & $\begin{array}{l}\text { Privatna kućanstava, usluge } \\
\text { za vlastite potrebe }\end{array}$ & 0,04 & 0,03 & 0,08 & 0,59 & 1,86 \\
\hline
\end{tabular}


PRILOG 2.

Međuregionalne isporuke intermedijarnih proizvoda i dobara i usluga za osobnu potrošnju, u milijunima HRK

\begin{tabular}{|c|c|c|c|c|c|c|c|}
\hline & & \multicolumn{2}{|c|}{$\begin{array}{l}\text { Međuregionalne } \\
\text { isporuke } \\
\text { intermedijarnih } \\
\text { proizvoda } \\
\end{array}$} & \multicolumn{2}{|c|}{$\begin{array}{c}\text { Isporuke za } \\
\text { osobnu potrošnju }\end{array}$} & \multicolumn{2}{|c|}{\begin{tabular}{|c|} 
Ukupno, \\
intermedijarne i \\
isporuke za finalnu \\
potrošnju \\
\end{tabular}} \\
\hline & & $\begin{array}{l}\text { Iz Kon u } \\
\text { Jadr }\end{array}$ & $\begin{array}{l}\text { Iz Jadr. } \\
\text { u Kont. }\end{array}$ & $\begin{array}{l}\text { Iz Kon u } \\
\text { Jadr }\end{array}$ & $\begin{array}{l}\text { Iz Jadr. } \\
\text { u Kont. }\end{array}$ & $\begin{array}{l}\text { Iz Kon u } \\
\text { Jadr }\end{array}$ & $\begin{array}{l}\text { Iz Jadr. } \\
\text { u Kont. }\end{array}$ \\
\hline A01 & Poljoprivreda i lov & 2470 & 1 & 1357 & 0 & 3827 & 1 \\
\hline A02 & Šumarstvo & 60 & 59 & 166 & 0 & 226 & 59 \\
\hline A03 & Ribarstvo & 0 & 176 & 0 & 300 & 0 & 475 \\
\hline B & Rudarstvo & 422 & 99 & 0 & 0 & 422 & 99 \\
\hline $\mathrm{C} 10-\mathrm{C} 12$ & $\begin{array}{l}\text { Prehrambeni proizvodi pića; } \\
\text { duhan }\end{array}$ & 2381 & 713 & 0 & 1368 & 2381 & 2082 \\
\hline $\mathrm{C} 13-\mathrm{C} 15$ & Tekstil; odjeća; koža & 311 & 0 & 184 & 0 & 495 & 0 \\
\hline $\mathrm{C} 16$ & Drvo i pluto, osim namještaja & 382 & 4 & 8 & 0 & 390 & 4 \\
\hline $\mathrm{C} 17$ & Papir & 460 & 19 & 51 & 0 & 511 & 19 \\
\hline $\mathrm{C} 18$ & $\begin{array}{l}\text { Tiskanje i umnožavanje } \\
\text { snimljenih zapisa }\end{array}$ & 363 & 41 & 13 & 0 & 376 & 41 \\
\hline C19 & Rafinirani naftni proizvodi & 896 & 75 & 185 & 0 & 1081 & 75 \\
\hline $\mathrm{C} 20$ & Kemikalije & 730 & 29 & 49 & 0 & 779 & 29 \\
\hline $\mathrm{C} 21$ & Farmaceutski proizvod & 447 & 0 & 122 & 0 & 568 & 0 \\
\hline $\mathrm{C} 22$ & Guma i plastika & 225 & 121 & 32 & 0 & 257 & 121 \\
\hline $\mathrm{C} 23$ & Ostali nemetalni mineralni proiz. & 182 & 145 & 0 & 12 & 182 & 156 \\
\hline $\mathrm{C} 24$ & Metal & 102 & 106 & 0 & 0 & 102 & 106 \\
\hline $\mathrm{C} 25$ & Gotovi metalni proizvodi & 349 & 47 & 1 & 0 & 350 & 47 \\
\hline $\mathrm{C} 26$ & $\begin{array}{l}\text { Računala, elektronički i optički } \\
\text { proiz. }\end{array}$ & 77 & 0 & 13 & 0 & 89 & 0 \\
\hline $\mathrm{C} 27$ & Električna oprema & 329 & 1 & 55 & 0 & 384 & 1 \\
\hline $\mathrm{C} 28$ & Strojevi i uređaji & 254 & 2 & 0 & 0 & 254 & 2 \\
\hline $\mathrm{C} 29$ & Motorna vozila i prikolice & 25 & 31 & 0 & 2 & 25 & 34 \\
\hline $\mathrm{C} 30$ & Ostala prijevozna sredstva & 48 & 328 & 0 & 32 & 48 & 360 \\
\hline C31_C32 & $\begin{array}{l}\text { Namještaj; Ostala prerađivačka } \\
\text { industrija }\end{array}$ & 305 & 9 & 40 & 0 & 345 & 9 \\
\hline $\mathrm{C} 33$ & $\begin{array}{l}\text { Popravak i instaliranje strojeva } \\
\text { i opreme }\end{array}$ & 185 & 109 & 1 & 0 & 186 & 109 \\
\hline
\end{tabular}


Ž. LOVRINČEVIĆ, D. MIKULIĆ, D. KEČEK: Izlazna gospodarska strategija Hrvatske u vrijeme pandemije COVID-19... EKONOMSKI PREGLED, 72 (3) 449-485 (2021)

\begin{tabular}{|c|c|c|c|c|c|c|c|}
\hline & & \multicolumn{2}{|c|}{$\begin{array}{l}\text { Međuregionalne } \\
\text { isporuke } \\
\text { intermedijarnih } \\
\text { proizvoda }\end{array}$} & \multicolumn{2}{|c|}{$\begin{array}{c}\text { Isporuke za } \\
\text { osobnu potrošnju }\end{array}$} & \multicolumn{2}{|c|}{$\begin{array}{c}\text { Ukupno, } \\
\text { intermedijarne i } \\
\text { isporuke za finalnu } \\
\text { potrošnju }\end{array}$} \\
\hline & & $\begin{array}{c}\text { Iz Kon u } \\
\text { Jadr }\end{array}$ & $\begin{array}{l}\text { Iz Jadr. } \\
\text { u Kont. }\end{array}$ & $\begin{array}{l}\text { Iz Kon u } \\
\text { Jadr }\end{array}$ & $\begin{array}{l}\text { Iz Jadr. } \\
\text { u Kont. }\end{array}$ & \begin{tabular}{|c|} 
Iz Kon u \\
Jadr
\end{tabular} & $\begin{array}{l}\text { Iz Jadr. } \\
\text { u Kont. }\end{array}$ \\
\hline $\mathrm{D}$ & $\begin{array}{l}\text { Opskrba električnom energijom, } \\
\text { plinom, parom }\end{array}$ & 1515 & 661 & 84 & 0 & 1599 & 661 \\
\hline E36 & $\begin{array}{l}\text { Skupljanje, pročišćavanje i } \\
\text { opskrba vodom }\end{array}$ & 62 & 46 & 0 & 76 & 62 & 122 \\
\hline E37-E39 & $\begin{array}{l}\text { Uklanjanje otpadnih voda; } \\
\text { zbrinjavanje otpada }\end{array}$ & 119 & 226 & 0 & 40 & 119 & 266 \\
\hline $\mathrm{F}$ & Građevinarstvo & 231 & 1342 & 0 & 14 & 231 & 1356 \\
\hline G45 & $\begin{array}{l}\text { Trgovina na veliko i na malo } \\
\text { motornim vozilima }\end{array}$ & 413 & 27 & 219 & 0 & 632 & 27 \\
\hline G46 & $\begin{array}{l}\text { Trgovina na veliko, osim } \\
\text { motornim vozilima }\end{array}$ & 1928 & 436 & 1159 & 0 & 3088 & 436 \\
\hline G47 & $\begin{array}{l}\text { Trgovina na malo, osim trgovine } \\
\text { motornim vozilima }\end{array}$ & 415 & 536 & 0 & 782 & 415 & 1317 \\
\hline H49 & $\begin{array}{l}\text { Kopneni prijevoz i cjevovodni } \\
\text { transport }\end{array}$ & 1404 & 147 & 534 & 0 & 1938 & 147 \\
\hline H50 & Vodeni prijevoz & 0 & 620 & 0 & 126 & 0 & 746 \\
\hline H51 & Zračni prijevoz & 135 & 0 & 56 & 0 & 191 & 0 \\
\hline H52 & $\begin{array}{l}\text { Skladištenje i prateće djelatnosti } \\
\text { u prijevozu }\end{array}$ & 285 & 811 & 0 & 0 & 285 & 811 \\
\hline H53 & Poštanske i kurirske djelatnosti & 36 & 128 & 0 & 2 & 36 & 130 \\
\hline I & Smještaj i usluživanja hrane i pića & 10 & 677 & 0 & 874 & 10 & 1551 \\
\hline J58 & Izdavačke djelatnosti & 61 & 10 & 52 & 0 & 113 & 10 \\
\hline J59_J60 & $\begin{array}{l}\text { Filmovi, TV program, snimanje } \\
\text { zvučnih zapisa }\end{array}$ & 193 & 1 & 131 & 0 & 324 & 1 \\
\hline $\mathrm{J} 61$ & Telekomunikacije & 1070 & 21 & 790 & 0 & 1859 & 21 \\
\hline J62_J63 & $\begin{array}{l}\text { Računalno programiranje, } \\
\text { savjetovanje }\end{array}$ & 434 & 13 & 14 & 0 & 448 & 13 \\
\hline K64 & $\begin{array}{l}\text { Financijske uslužne djelatnosti, } \\
\text { osim osiguranja }\end{array}$ & 1650 & 94 & 930 & 0 & 2580 & 94 \\
\hline K65 & $\begin{array}{l}\text { Osiguranje, reosiguranje i } \\
\text { mirovinski fondovi }\end{array}$ & 260 & 18 & 331 & 0 & 591 & 18 \\
\hline K66 & Pomoćne financijske usluge & 93 & 19 & 60 & 0 & 152 & 19 \\
\hline L68A & Poslovanje nekretninama & 491 & 719 & 0 & 93 & 491 & 812 \\
\hline L68B & Imputirana renta & 0 & 0 & 0 & 3612 & 0 & 3612 \\
\hline $\begin{array}{l}\text { M69- } \\
\text { M70 }\end{array}$ & Pravne i računovodstvene usluge & 873 & 130 & 89 & 0 & 962 & 130 \\
\hline
\end{tabular}




\begin{tabular}{|c|c|c|c|c|c|c|c|}
\hline & & \multicolumn{2}{|c|}{$\begin{array}{l}\text { Međuregionalne } \\
\text { isporuke } \\
\text { intermedijarnih } \\
\text { proizvoda }\end{array}$} & \multicolumn{2}{|c|}{$\begin{array}{c}\text { Isporuke za } \\
\text { osobnu potrošnju }\end{array}$} & \multicolumn{2}{|c|}{$\begin{array}{c}\text { Ukupno, } \\
\text { intermedijarne i } \\
\text { isporuke za finalnu } \\
\text { potrošnju }\end{array}$} \\
\hline & & \begin{tabular}{|c|} 
Iz Kon u \\
Jadr
\end{tabular} & $\begin{array}{l}\text { Iz Jadr. } \\
\text { u Kont. }\end{array}$ & \begin{tabular}{|c|} 
Iz Kon u \\
Jadr
\end{tabular} & $\begin{array}{l}\text { Iz Jadr. } \\
\text { u Kont. }\end{array}$ & \begin{tabular}{|c|} 
Iz Kon u \\
Jadr
\end{tabular} & $\begin{array}{l}\text { Iz Jadr. } \\
\text { u Kont. }\end{array}$ \\
\hline M71 & $\begin{array}{l}\text { Arhitektonske djelatnosti i } \\
\text { inženjerstvo }\end{array}$ & 462 & 283 & 8 & 0 & 470 & 283 \\
\hline M72 & Znanstveno istraživanje i razvoj & 101 & 10 & 0 & 0 & 101 & 10 \\
\hline M73 & Promidžba i istraživanje tržišta & 901 & 5 & 2 & 0 & 903 & 5 \\
\hline $\mathrm{N}$ & $\begin{array}{l}\text { Ostale stručne, znanstvene i } \\
\text { tehničke usluge }\end{array}$ & 203 & 16 & 13 & 0 & 216 & 16 \\
\hline N77 & $\begin{array}{l}\text { Iznajmljivanje i davanje u zakup } \\
\text { (leasing) }\end{array}$ & 139 & 619 & 0 & 28 & 139 & 647 \\
\hline N78 & Djelatnosti zapošljavanja & 164 & 17 & 11 & 0 & 175 & 17 \\
\hline N79 & $\begin{array}{l}\text { Putničke agencije, organizatori } \\
\text { putovanja }\end{array}$ & 34 & 389 & 0 & 239 & 34 & 629 \\
\hline N80-N82 & $\begin{array}{l}\text { Zaštitne i istražne usluge; } \\
\text { Administrativne usluge }\end{array}$ & 277 & 100 & 18 & 0 & 295 & 100 \\
\hline $\mathrm{O}$ & $\begin{array}{l}\text { Javna uprava i obrana; obvezno } \\
\text { soc. osiguranje }\end{array}$ & 34 & 32 & 2 & 0 & 36 & 32 \\
\hline $\mathrm{P}$ & Obrazovanje & 81 & 59 & 50 & 0 & 131 & 59 \\
\hline Q86 & Zdravstvena zaštita & 54 & 10 & 77 & 0 & 131 & 10 \\
\hline Q87_Q88 & Socijalna skrb & 4 & 0 & 25 & 0 & 30 & 0 \\
\hline R90-R92 & $\begin{array}{l}\text { Kreativne, umjetničke i zabavne } \\
\text { djelatnosti }\end{array}$ & 73 & 62 & 0 & 80 & 73 & 142 \\
\hline R93 & $\begin{array}{l}\text { Sportske i rekreacijske } \\
\text { djelatnosti }\end{array}$ & 23 & 17 & 0 & 23 & 23 & 40 \\
\hline S94 & Djelatnosti članskih organizacija & 50 & 74 & 0 & 0 & 50 & 74 \\
\hline S95 & $\begin{array}{l}\text { Popravak računala i predmeta za } \\
\text { osobnu uporabu }\end{array}$ & 16 & 22 & 0 & 1 & 16 & 23 \\
\hline S96 & Ostale osobne uslužne djelatnosti & 113 & 27 & 0 & 67 & 113 & 94 \\
\hline \multirow[t]{2}{*}{$\mathrm{T}$} & $\begin{array}{l}\text { Privatna kućanstava, usluge za } \\
\text { vlastite potrebe }\end{array}$ & 0 & 0 & 0 & 36 & 0 & 36 \\
\hline & Ukupno & 25410 & 10540 & 6933 & 7808 & 32343 & 18348 \\
\hline
\end{tabular}


Ž. LOVRINČEVIĆ, D. MIKULIĆ, D. KEČEK: Izlazna gospodarska strategija Hrvatske u vrijeme pandemije COVID-19... EKONOMSKI PREGLED, 72 (3) 449-485 (2021)

PRILOG 3.

Multiplikatori outputa, te regionalni učinci jediničnog porasta finalne potražnje za proizvodima koje isporučuju poduzetnici iz Kontitentalne Hrvatske na BDV i zaposlenosti, razina odjeljaka

\begin{tabular}{|c|c|c|c|c|c|c|c|c|}
\hline & $\begin{array}{c}\text { Mult. } \\
\text { Outputa }\end{array}$ & $\begin{array}{l}\text { Mult__ } \\
\text { BDV }\end{array}$ & $\begin{array}{c}\text { Multi_ } \\
\text { zap }\end{array}$ & BDV & $\begin{array}{c}\mathrm{BDV}_{-} \\
\text {Kont }\end{array}$ & $\begin{array}{c}\mathrm{BDV}_{-} \\
\text {Jadr }\end{array}$ & $\begin{array}{l}\text { Zap_ } \\
\text { Kont }\end{array}$ & Zap_Jadr \\
\hline A01 & 1,67 & 1,64 & 1,39 & 0,75 & 0,71 & 0,04 & 6,61 & 0,21 \\
\hline A02 & 1,62 & 1,51 & 1,33 & 0,84 & 0,82 & 0,02 & 7,01 & 0,09 \\
\hline A03 & 2,00 & 2,06 & 1,91 & 0,86 & 0,70 & 0,16 & 4,09 & 0,94 \\
\hline B & 1,54 & 1,71 & 2,30 & 0,57 & 0,55 & 0,03 & 1,69 & 0,12 \\
\hline $\mathrm{C} 10-\mathrm{C} 12$ & 1,96 & 2,23 & 2,08 & 0,75 & 0,73 & 0,03 & 5,05 & 0,12 \\
\hline C13-C15 & 1,66 & 1,91 & 1,42 & 0,59 & 0,54 & 0,05 & 4,81 & 0,25 \\
\hline $\mathrm{C} 16$ & 2,06 & 2,50 & 2,14 & 0,79 & 0,73 & 0,06 & 5,22 & 0,33 \\
\hline $\mathrm{C} 17$ & 1,83 & 2,34 & 2,06 & 0,58 & 0,54 & 0,04 & 2,90 & 0,22 \\
\hline C18 & 1,71 & 1,82 & 1,67 & 0,66 & 0,63 & 0,03 & 3,39 & 0,13 \\
\hline C19 & 1,30 & 1,46 & 2,68 & 0,40 & 0,40 & 0,01 & 0,77 & 0,04 \\
\hline $\mathrm{C} 20$ & 1,84 & 2,38 & 2,17 & 0,58 & 0,52 & 0,06 & 2,24 & 0,25 \\
\hline $\mathrm{C} 21$ & 1,74 & 1,67 & 2,69 & 0,75 & 0,70 & 0,05 & 1,81 & 0,26 \\
\hline $\mathrm{C} 22$ & 1,70 & 1,86 & 1,64 & 0,61 & 0,59 & 0,02 & 3,22 & 0,11 \\
\hline $\mathrm{C} 23$ & 1,95 & 2,11 & 1,95 & 0,74 & 0,72 & 0,02 & 3,33 & 0,11 \\
\hline $\mathrm{C} 24$ & 1,58 & 1,78 & 1,47 & 0,57 & 0,55 & 0,01 & 3,37 & 0,07 \\
\hline $\mathrm{C} 25$ & 1,68 & 1,74 & 1,61 & 0,72 & 0,69 & 0,03 & 3,68 & 0,18 \\
\hline $\mathrm{C} 26$ & 1,60 & 1,72 & 1,81 & 0,64 & 0,59 & 0,05 & 2,49 & 0,27 \\
\hline $\mathrm{C} 27$ & 1,63 & 1,82 & 1,80 & 0,62 & 0,57 & 0,05 & 2,64 & 0,27 \\
\hline $\mathrm{C} 28$ & 1,74 & 1,97 & 1,73 & 0,66 & 0,61 & 0,06 & 3,37 & 0,29 \\
\hline $\mathrm{C} 29$ & 1,65 & 1,85 & 1,59 & 0,62 & 0,60 & 0,01 & 3,40 & 0,07 \\
\hline $\mathrm{C} 30$ & 1,94 & 2,49 & 1,93 & 0,68 & 0,65 & 0,03 & 3,84 & 0,17 \\
\hline C31_C32 & 1,74 & 1,85 & 1,56 & 0,68 & 0,64 & 0,04 & 4,56 & 0,19 \\
\hline C33 & 1,76 & 1,82 & 1,77 & 0,76 & 0,74 & 0,03 & 3,48 & 0,14 \\
\hline $\mathrm{D}$ & 1,71 & 1,81 & 2,54 & 0,64 & 0,63 & 0,01 & 1,54 & 0,06 \\
\hline E36 & 1,51 & 1,36 & 1,33 & 0,88 & 0,87 & 0,01 & 3,51 & 0,04 \\
\hline E37-E39 & 1,68 & 1,64 & 1,53 & 0,84 & 0,82 & 0,02 & 4,36 & 0,10 \\
\hline $\mathrm{F}$ & 1,85 & 1,97 & 1,73 & 0,74 & 0,72 & 0,03 & 4,17 & 0,14 \\
\hline G45 & 1,59 & 1,54 & 1,44 & 0,83 & 0,81 & 0,03 & 3,90 & 0,13 \\
\hline G46 & 1,67 & 1,64 & 1,65 & 0,79 & 0,76 & 0,03 & 3,49 & 0,15 \\
\hline G47 & 1,58 & 1,52 & 1,35 & 0,80 & 0,79 & 0,01 & 4,74 & 0,06 \\
\hline
\end{tabular}




\begin{tabular}{|c|c|c|c|c|c|c|c|c|}
\hline & $\begin{array}{c}\text { Mult. } \\
\text { Outputa }\end{array}$ & $\begin{array}{l}\text { Mult__ } \\
\text { BDV }\end{array}$ & $\begin{array}{c}\text { Multi_ } \\
\text { zap }\end{array}$ & $\mathrm{BDV}$ & $\begin{array}{c}\mathrm{BDV}_{-} \\
\text {Kont }\end{array}$ & $\begin{array}{c}\mathrm{BDV}_{-} \\
\mathrm{Jadr}\end{array}$ & $\begin{array}{l}\text { Zap_ } \\
\text { Kont }\end{array}$ & Zap_Jadr \\
\hline H49 & 1,68 & 1,70 & 1,53 & 0,74 & 0,72 & 0,03 & 3,61 & 0,13 \\
\hline H50 & 1,74 & 1,80 & 1,61 & 0,70 & 0,69 & 0,02 & 3,45 & 0,07 \\
\hline H51 & 2,17 & 3,48 & 4,91 & 0,71 & 0,59 & 0,12 & 2,27 & 0,67 \\
\hline H52 & 1,81 & 1,83 & 1,65 & 0,81 & 0,78 & 0,03 & 3,97 & 0,11 \\
\hline H53 & 1,31 & 1,19 & 1,14 & 0,92 & 0,92 & 0,01 & 5,19 & 0,04 \\
\hline I & 1,63 & 1,49 & 1,45 & 0,83 & 0,81 & 0,01 & 4,69 & 0,05 \\
\hline $\mathrm{J} 58$ & 1,74 & 1,68 & 1,71 & 0,80 & 0,78 & 0,02 & 3,70 & 0,11 \\
\hline J59_J60 & 1,70 & 1,74 & 1,85 & 0,82 & 0,78 & 0,04 & 2,82 & 0,21 \\
\hline J61 & 1,74 & 1,73 & 2,73 & 0,87 & 0,83 & 0,04 & 1,84 & 0,20 \\
\hline J62_J63 & 1,52 & 1,44 & 1,55 & 0,85 & 0,82 & 0,03 & 2,85 & 0,16 \\
\hline K64 & 1,33 & 1,24 & 1,58 & 0,92 & 0,90 & 0,01 & 1,85 & 0,07 \\
\hline K65 & 1,73 & 1,88 & 1,44 & 0,86 & 0,83 & 0,03 & 4,66 & 0,13 \\
\hline K66 & 1,50 & 1,45 & 1,69 & 0,89 & 0,86 & 0,02 & 2,43 & 0,11 \\
\hline L68A & 1,53 & 1,46 & 1,54 & 0,84 & 0,83 & 0,01 & 3,00 & 0,06 \\
\hline L68B & 1,16 & 1,09 & 0,00 & 0,98 & 0,98 & 0,00 & 0,32 & 0,01 \\
\hline M69_M70 & 1,55 & 1,48 & 1,54 & 0,89 & 0,86 & 0,02 & 3,32 & 0,12 \\
\hline M71 & 1,69 & 1,63 & 1,66 & 0,85 & 0,83 & 0,02 & 3,72 & 0,10 \\
\hline M72 & 1,42 & 1,30 & 1,39 & 0,86 & 0,83 & 0,03 & 3,08 & 0,14 \\
\hline M73 & 1,91 & 2,30 & 2,32 & 0,80 & 0,72 & 0,08 & 3,15 & 0,40 \\
\hline $\mathrm{N}$ & 1,56 & 1,49 & 1,38 & 0,83 & 0,80 & 0,03 & 4,23 & 0,15 \\
\hline N77 & 1,57 & 1,51 & 1,83 & 0,83 & 0,81 & 0,02 & 2,33 & 0,07 \\
\hline N78 & 1,45 & 1,33 & 1,17 & 0,90 & 0,88 & 0,02 & 5,97 & 0,11 \\
\hline N79 & 1,61 & 1,84 & 1,84 & 0,45 & 0,40 & 0,05 & 1,93 & 0,32 \\
\hline N80-N82 & 1,48 & 1,37 & 1,19 & 0,85 & 0,84 & 0,02 & 6,74 & 0,08 \\
\hline $\mathrm{O}$ & 1,58 & 1,58 & 1,38 & 0,78 & 0,76 & 0,02 & 4,48 & 0,10 \\
\hline $\mathrm{P}$ & 1,26 & 1,17 & 1,12 & 0,92 & 0,91 & 0,01 & 6,50 & 0,03 \\
\hline Q86 & 1,43 & 1,32 & 1,25 & 0,80 & 0,79 & 0,01 & 4,20 & 0,06 \\
\hline Q87_Q88 & 1,41 & 1,28 & 1,11 & 0,85 & 0,84 & 0,01 & 9,41 & 0,07 \\
\hline R90-R92 & 1,56 & 1,49 & 1,39 & 0,83 & 0,81 & 0,02 & 4,23 & 0,08 \\
\hline R93 & 1,66 & 1,68 & 1,67 & 0,81 & 0,79 & 0,02 & 3,60 & 0,08 \\
\hline S94 & 1,73 & 1,83 & 1,73 & 0,76 & 0,74 & 0,02 & 3,68 & 0,11 \\
\hline S95 & 1,44 & 1,41 & 1,28 & 0,76 & 0,75 & 0,01 & 4,43 & 0,05 \\
\hline S96 & 1,45 & 1,33 & 1,20 & 0,86 & 0,85 & 0,01 & 6,22 & 0,06 \\
\hline $\mathrm{T}$ & 1,00 & 1,00 & 1,00 & 1,00 & 1,00 & 0,00 & 12,76 & 0,00 \\
\hline
\end{tabular}


Ž. LOVRINČEVIĆ, D. MIKULIĆ, D. KEČEK: Izlazna gospodarska strategija Hrvatske u vrijeme pandemije COVID-19.. EKONOMSKI PREGLED, 72 (3) 449-485 (2021)

PRILOG 4.

Multiplikatori outputa, te regionalni učinci jediničnog porasta finalne potražnje za proizvodima koje isporučuju poduzetnici iz Jadranske Hrvatske na BDV i zaposlenosti, razina odjeljaka

\begin{tabular}{|c|c|c|c|c|c|c|c|c|}
\hline & $\begin{array}{c}\text { Mult. } \\
\text { outputa }\end{array}$ & $\begin{array}{l}\text { Mult__ } \\
\text { BDV }\end{array}$ & $\begin{array}{c}\text { Multi__ } \\
\text { zap }\end{array}$ & $\mathrm{BDV}$ & $\begin{array}{c}\mathrm{BDV}_{-} \\
\text {Kont }\end{array}$ & $\begin{array}{c}\text { BDV__ }_{-} \\
\text {Jadr }\end{array}$ & $\begin{array}{l}\text { Zap_ } \\
\text { Kont }\end{array}$ & $\begin{array}{l}\text { Zap_ } \\
\text { Jadr }\end{array}$ \\
\hline A01 & 1,67 & 1,66 & 1,46 & 0,73 & 0,10 & 0,63 & 0,86 & 5,17 \\
\hline A02 & 1,62 & 1,50 & 1,34 & 0,86 & 0,08 & 0,77 & 0,63 & 6,68 \\
\hline A03 & 2,00 & 2,07 & 2,00 & 0,86 & 0,26 & 0,59 & 1,36 & 3,41 \\
\hline B & 1,54 & 1,71 & 2,06 & 0,57 & 0,04 & 0,52 & 0,18 & 2,01 \\
\hline $\mathrm{C} 10-\mathrm{C} 12$ & 1,96 & 2,26 & 3,18 & 0,74 & 0,22 & 0,52 & 1,52 & 2,21 \\
\hline C13-C15 & 1,66 & 1,88 & 1,42 & 0,60 & 0,07 & 0,53 & 0,51 & 4,86 \\
\hline $\mathrm{C} 16$ & 2,06 & 2,46 & 2,10 & 0,80 & 0,11 & 0,69 & 0,73 & 5,21 \\
\hline $\mathrm{C} 17$ & 1,83 & 2,30 & 2,10 & 0,59 & 0,08 & 0,50 & 0,41 & 2,89 \\
\hline C18 & 1,71 & 1,82 & 1,68 & 0,65 & 0,08 & 0,58 & 0,37 & 3,39 \\
\hline C19 & 1,30 & 1,46 & 2,87 & 0,40 & 0,02 & 0,39 & 0,06 & 0,83 \\
\hline $\mathrm{C} 20$ & 1,84 & 2,29 & 2,21 & 0,59 & 0,05 & 0,54 & 0,23 & 2,46 \\
\hline $\mathrm{C} 21$ & 1,74 & 1,69 & 2,39 & 0,75 & 0,06 & 0,70 & 0,19 & 2,29 \\
\hline $\mathrm{C} 22$ & 1,70 & 1,85 & 1,69 & 0,61 & 0,09 & 0,52 & 0,41 & 3,01 \\
\hline $\mathrm{C} 23$ & 1,95 & 2,10 & 2,04 & 0,74 & 0,13 & 0,61 & 0,53 & 2,87 \\
\hline $\mathrm{C} 24$ & 1,58 & 1,81 & 1,56 & 0,55 & 0,06 & 0,49 & 0,26 & 3,01 \\
\hline $\mathrm{C} 25$ & 1,68 & 1,76 & 1,63 & 0,71 & 0,05 & 0,66 & 0,23 & 3,93 \\
\hline $\mathrm{C} 26$ & 1,60 & 1,70 & 1,60 & 0,65 & 0,03 & 0,62 & 0,14 & 3,50 \\
\hline $\mathrm{C} 27$ & 1,63 & 1,78 & 1,63 & 0,63 & 0,05 & 0,58 & 0,22 & 3,45 \\
\hline $\mathrm{C} 28$ & 1,74 & 1,94 & 1,73 & 0,67 & 0,05 & 0,62 & 0,22 & 3,76 \\
\hline $\mathrm{C} 29$ & 1,65 & 1,87 & 1,57 & 0,61 & 0,10 & 0,50 & 0,44 & 3,35 \\
\hline $\mathrm{C} 30$ & 1,94 & 3,14 & 2,03 & 0,59 & 0,29 & 0,30 & 1,29 & 2,58 \\
\hline C31_C32 & 1,74 & 1,82 & 1,55 & 0,69 & 0,07 & 0,63 & 0,42 & 4,71 \\
\hline C33 & 1,76 & 1,93 & 1,70 & 0,70 & 0,09 & 0,62 & 0,35 & 3,77 \\
\hline $\mathrm{D}$ & 1,71 & 1,80 & 2,43 & 0,64 & 0,07 & 0,57 & 0,25 & 1,49 \\
\hline E36 & 1,51 & 1,36 & 1,32 & 0,88 & 0,10 & 0,78 & 0,34 & 3,52 \\
\hline E37-E39 & 1,68 & 1,66 & 1,49 & 0,82 & 0,12 & 0,70 & 0,51 & 4,61 \\
\hline $\mathrm{F}$ & 1,85 & 1,99 & 1,92 & 0,73 & 0,13 & 0,60 & 0,56 & 3,11 \\
\hline G45 & 1,59 & 1,53 & 1,39 & 0,83 & 0,06 & 0,77 & 0,23 & 4,68 \\
\hline G46 & 1,67 & 1,65 & 1,57 & 0,78 & 0,08 & 0,70 & 0,35 & 3,90 \\
\hline G47 & 1,58 & 1,51 & 1,32 & 0,81 & 0,11 & 0,69 & 0,51 & 5,06 \\
\hline
\end{tabular}




\begin{tabular}{|c|c|c|c|c|c|c|c|c|}
\hline & $\begin{array}{c}\text { Mult. } \\
\text { outputa }\end{array}$ & $\begin{array}{l}\text { Mult_ } \\
\text { BDV }\end{array}$ & $\begin{array}{c}\text { Multi_ } \\
\text { zap }\end{array}$ & $\mathrm{BDV}$ & $\begin{array}{c}\text { BDV }_{-} \\
\text {Kont }\end{array}$ & $\begin{array}{c}\text { BDV } \\
\text { Jadr }\end{array}$ & $\begin{array}{l}\text { Zap_ } \\
\text { Kont }\end{array}$ & $\begin{array}{c}\text { Zap_ } \\
\text { Jadr }\end{array}$ \\
\hline $\mathrm{H} 49$ & 1,68 & 1,71 & 1,49 & 0,73 & 0,06 & 0,67 & 0,26 & 4,05 \\
\hline $\mathrm{H} 50$ & 1,74 & 1,67 & 2,04 & 0,78 & 0,29 & 0,49 & 1,24 & 1,38 \\
\hline H51 & 2,17 & 3,30 & 4,43 & 0,71 & 0,08 & 0,64 & 0,33 & 2,91 \\
\hline H52 & 1,81 & 1,84 & 1,62 & 0,79 & 0,15 & 0,64 & 0,63 & 3,77 \\
\hline $\mathrm{H} 53$ & 1,31 & 1,19 & 1,14 & 0,92 & 0,05 & 0,87 & 0,21 & 5,22 \\
\hline I & 1,63 & 1,48 & 1,55 & 0,83 & 0,21 & 0,62 & 1,14 & 2,89 \\
\hline J58 & 1,74 & 1,67 & 1,60 & 0,80 & 0,06 & 0,73 & 0,29 & 4,38 \\
\hline J59_J60 & 1,70 & 1,73 & 1,69 & 0,82 & 0,11 & 0,71 & 0,42 & 3,49 \\
\hline J61 & 1,74 & 1,73 & 2,39 & 0,87 & 0,12 & 0,75 & 0,33 & 2,18 \\
\hline J62_J63 & 1,52 & 1,44 & 1,45 & 0,85 & 0,06 & 0,79 & 0,22 & 3,67 \\
\hline K64 & 1,33 & 1,24 & 1,65 & 0,91 & 0,04 & 0,87 & 0,13 & 1,88 \\
\hline K65 & 1,73 & 1,88 & 1,48 & 0,86 & 0,05 & 0,81 & 0,22 & 4,69 \\
\hline K66 & 1,50 & 1,45 & 1,78 & 0,89 & 0,05 & 0,83 & 0,18 & 2,51 \\
\hline L68A & 1,53 & 1,45 & 1,55 & 0,84 & 0,11 & 0,73 & 0,42 & 2,74 \\
\hline L68B & 1,16 & 1,09 & 0,00 & 0,98 & 0,05 & 0,93 & 0,19 & 0,14 \\
\hline M69_M70 & 1,55 & 1,48 & 1,41 & 0,88 & 0,08 & 0,81 & 0,30 & 4,37 \\
\hline M71 & 1,69 & 1,63 & 1,58 & 0,85 & 0,08 & 0,77 & 0,31 & 4,08 \\
\hline M72 & 1,42 & 1,30 & 1,28 & 0,86 & 0,04 & 0,82 & 0,16 & 4,34 \\
\hline M73 & 1,91 & 2,16 & 1,69 & 0,84 & 0,08 & 0,76 & 0,35 & 5,22 \\
\hline $\mathrm{N}$ & 1,56 & 1,49 & 1,33 & 0,82 & 0,05 & 0,77 & 0,20 & 5,19 \\
\hline N77 & 1,57 & 1,54 & 1,72 & 0,79 & 0,10 & 0,68 & 0,42 & 2,37 \\
\hline N78 & 1,45 & 1,34 & 1,16 & 0,89 & 0,04 & 0,85 & 0,14 & 7,08 \\
\hline N79 & 1,61 & 1,90 & 1,71 & 0,43 & 0,08 & 0,34 & 0,35 & 2,23 \\
\hline N80-N82 & 1,48 & 1,37 & 1,17 & 0,85 & 0,07 & 0,78 & 0,32 & 7,92 \\
\hline $\mathrm{O}$ & 1,58 & 1,57 & 1,36 & 0,78 & 0,09 & 0,69 & 0,38 & 4,85 \\
\hline $\mathrm{P}$ & 1,26 & 1,17 & 1,11 & 0,92 & 0,03 & 0,89 & 0,16 & 7,37 \\
\hline Q86 & 1,43 & 1,32 & 1,27 & 0,80 & 0,08 & 0,72 & 0,30 & 4,02 \\
\hline Q87_Q88 & 1,41 & 1,28 & 1,11 & 0,85 & 0,04 & 0,81 & 0,22 & 9,26 \\
\hline R90-R92 & 1,56 & 1,48 & 1,40 & 0,83 & 0,10 & 0,72 & 0,42 & 3,90 \\
\hline R93 & 1,66 & 1,68 & 1,70 & 0,80 & 0,13 & 0,67 & 0,59 & 3,20 \\
\hline S94 & 1,73 & 1,82 & 1,78 & 0,76 & 0,12 & 0,64 & 0,53 & 3,36 \\
\hline S95 & 1,44 & 1,41 & 1,38 & 0,76 & 0,08 & 0,68 & 0,32 & 3,46 \\
\hline S96 & 1,45 & 1,33 & 1,21 & 0,85 & 0,07 & 0,78 & 0,30 & 5,86 \\
\hline $\mathrm{T}$ & 1,00 & 1,00 & 1,00 & 1,00 & 0,00 & 1,00 & 0,00 & 21,36 \\
\hline
\end{tabular}




\title{
CROATIAN ECONOMIC EXIT STRATEGY DURING COVID-19 PANDEMIC AND IMPORTANCE OF REGIONAL ECONOMIC STRUCTURE
}

\begin{abstract}
Summary
The aim of the paper is to identify the sectors with the highest potential to mitigate the negative economic consequences of the spread of COVID-19 virus in Croatia based on the multiplicative effects and intensity of regional integration. Croatia has been divided in two regions, Continental Croatia and Adriatic Croatia. Cross-industry location quotient (CILQ) methodology was used to compile the regional input-output tables. The method is based on the specialization of individual regions in the production of specific groups of products, based on which national technical coefficients are adjusted at the level of individual regions. The contribution of the research is based on the lack of empirical literature that would deal with regional input-output analysis for the Croatian economy. Results of this paper can be used as a basis for defining economic exit strategy aimed at faster recovery from the recession. The highest multiplicative effects and the highest intensity of regional integration have been observed in manufacturing, agriculture and construction sectors. This group of activities can, with some precautions, take place so far without the high risk of spreading the virus. Stimulation of these activities results in positive effects even in the short term. Due to the high multiplicative effects, a positive impulse will spread to other activities and regions. In addition to these activities, emphasis should also be placed on improving health system and information and communication technology sector, where indirect economic effects are slightly lower but will be crucial for the smooth running of economic activity in the future. Tourism sector has shallow multiplier, but above average share of final uses. It has significant impact on government budget revenues.
\end{abstract}

Keywords: regional input-output tables, multiplicative effects, Covid-19 virus, location quotients. 